bioRxiv preprint doi: https://doi.org/10.1101/2021.04.25.441366; this version posted May 24, 2021. The copyright holder for this preprint (which was not certified by peer review) is the author/funder, who has granted bioRxiv a license to display the preprint in perpetuity. It is made available under aCC-BY 4.0 International license.

\title{
Standardized genome-wide function prediction enables comparative functional genomics: a new application area for Gene Ontologies in plants
}

\author{
Leila Fattel $^{1, *}$, Dennis Psaroudakis ${ }^{2, *, \dagger}$, Colleen F. Yanarella ${ }^{1, \ddagger}$, Kevin Chiteri $^{1, \ddagger}$, Haley A. Dostalik ${ }^{1, \ddagger}$, Parnal \\ Joshi $^{4, \ddagger}$, Dollye C. Starr ${ }^{1, \ddagger}, \mathrm{Ha} \mathrm{Vu}^{5, \ddagger}$, Kokulapalan Wimalanathan ${ }^{5, \S}$, and Carolyn J. Lawrence-Dill ${ }^{1,5, \uparrow}$ \\ ${ }^{1}$ Department of Agronomy, Iowa State University \\ ${ }^{2}$ Department of Plant Pathology and Microbiology, Iowa State University \\ ${ }^{3}$ Department of Ecology, Evolution and Organismal Biology, Iowa State University \\ ${ }^{4}$ Department of Veterinary Microbiology and Preventative Medicine, Iowa State University \\ ${ }^{5}$ Department of Genetics, Development and Cell Biology, Iowa State University
}

(Dated: May 24, 2021)

Background Genome-wide gene function annotations are useful for hypothesis generation and for prioritizing candidate genes responsible for phenotypes of interest. We functionally annotated the genes of 18 crop plant genomes across 14 species using the GOMAP pipeline.

Results By comparison to existing GO annotation datasets available for a subset of these genomes, GOMAP-generated datasets cover more genes, assign more GO terms, and produce datasets similar in quality (based on precision and recall metrics using existing gold standards as the basis for comparison). From there, we sought to determine whether the datasets could be used in tandem to carry out comparative functional genomics analyses. As a test of the idea and a proof of concept, we created parsimony and distance-based dendrograms of relatedness based on functions for all 18 genomes. These dendrograms were compared to well-established species-level phylogenies to determine whether trees derived through the analysis of gene function agree with known evolutionary histories, which they largely do. Where discrepancies were observed, we determined branch support based on jack-knifing then removed individual annotation sets by genome to identify the annotation sets causing errant relationships.

Conclusions Based on the results of these analyses, it is clear that for genome assembly and annotation products of similar quality, GOMAP-derived functional annotations used together across species do retain sufficient biological signal to recover known phylogenetic relationships, indicating that comparative functional genomics across species based on GO data hold promise as a tool for generating novel hypotheses about gene function and traits.

Keywords: Gene function; ontology; plants; comparative genomics; functional genomics

\section{BACKGROUND}

Phenotypes and traits that have long been the focus of interest for biological investigations. Phenotypes are a result of a complex interplay between functions of genes and environmental cues. In an effort to organize and model gene functions, various systems of classification have been developed including systems like KEGG (the Kyoto Encyclopedia of Gens and Genomes), which is focused on protein function including gene activities superimposed on metabolic pathways. Other such systems include the various Cyc databases, MapMan, and the Gene Ontologies (GO), a vocabulary of gene functions organized as a directed acyclic graph, which makes it innately tractable for computational analysis $[1,2,3,4]$.

GO-based gene function annotation involves the association of GO terms to individual genes. Functions may be assigned to genes based on different types of evidence for the association. For example, functional predictions

\footnotetext{
${ }^{*}$ Contributed equally.

${ }^{\dagger}$ Current address: Department of Molecular Biology, Leibniz Institute of Plant Genetics and Crop Plant Research (IPK), 06466 Seeland, OT Gatersleben, Germany

${ }^{\ddagger}$ Listed alphabetically.

$\S$ kokul@bioinformapping.com

$\uparrow_{\text {triffid@iastate.edu }}$
}

can be inferred from experiments (EXP), inferred from expression pattern (IEP), and more [5]. Computational pipelines often are used to generate functional predictions for newly sequenced genomes, where the genome is first sequenced and assembled, then gene structures (gene models) are predicted, then functions are associated with those gene predictions. Genome-wide gene function prediction datasets are frequently used to analyze gene expression studies, to prioritize candidate genes linked to a phenotype of interest, to design experiments aimed at characterizing functions of genes, and more $[6$, $7,8]$. Clearly, how well a gene function prediction set models reality is strongly influenced by the how complete and correct the underlying genome assembly and gene structure annotations are coupled with how well the software used to predict functions performs.

GOMAP (the Gene Ontology Meta Annotator for Plants) is a gene function prediction system for plants that generates high-coverage and reproducible functional annotations [9]. The system employs multiple functional prediction approaches, including sequence similarity, protein domain presence, and mixed-method pipelines developed to compete in the Critical Assessment of Function Annotation (CAFA) Challenge [10], a community challenge that has advanced the performance of gene function prediction pipelines over the course of five organized competitions [11].

We previously annotated gene functions for the maize 
bioRxiv preprint doi: https://doi.org/10.1101/2021.04.25.441366; this version posted May 24, 2021. The copyright holder for this preprint (which was not certified by peer review) is the author/funder, who has granted bioRxiv a license to display the preprint in perpetuity. It is made available under aCC-BY 4.0 International license.

B73 genome and demonstrated that GOMAP's predicted functions were closer to curated gene-term associations from the literature than those of other community functional annotation datasets ([12]). Using the newly containerized GOMAP system ([9]), we report the functional annotation of 18 plant genomes across the 14 crop plant species shown in Table I.

We were curious to find out whether the datasets could be used together as a set to reveal biologically relevant and interesting perspectives. As a first step in that direction, we describe here a method by which we used gene function annotations to generate dendrograms of genome-level similarity in function (see Figure 1 for process overview). This idea is similar to that of Zhu et al., who determined the evolutionary relationships among microorganisms based on whole-genome functional similarity [13]. Here we expand on that approach, analyzing genome-wide GO assignments to generate parsimony and distance-based dendrograms. We compared these with well-established species phylogenies (Figure 2) to determine whether trees derived from gene function agree with evolutionary histories and to better consider whether these datasets could be used together for comparative functional genomics analyses.

\section{RESULTS OF ANALYSES}

\section{A. Overview}

Figure 1 gives an overview of the general workflow of analyses. In brief, gene function annotation sets were created and compiled for each genome. For those with existing annotation sets available, the datasets were compared. From there, matrices that included genomes as rows and terms as columns were generated. These were used directly to build parsimony trees or to create distance matrices for neighbor-joining tree construction [32, $33,34]$. In subsequent analyses, jackknifing was used to remove terms (columns) or to remove genomes (rows) to map the source of signal for treebuilding results [35].

\section{B. Functional Annotation Sets Produced}

Table II shows quantitative attributes of each of the annotation sets. In summary, GOMAP covers all annotated genomes with at least one annotation per gene, and provides between 3.8 and 12.1 times as many annotations as Gramene or Phytozome [36, 37].

Quality evaluation of gene function predictions is not trivial and is approached by different research groups in differnet ways. Most often datasets are assessed by comparing the set of predicted functions for a given gene to a Gold Standard consisting of annotations that are assumed to be correct. This assumption of correctness can be based on any number of criteria. Here we used as our Gold Standard dataset all annotations present in
Gramene that had a non-IEA (non-Inferred by Electronic Annotation) evidence code. This enabled us to assess ten of the eighteen annotation sets, as shown in Table II. It is perhaps noteworthy that the IEA and non-IEA annotation sets from Gramene frequently contain overlaps, indicating that some of the predicted annotations were manually confirmed afterwards by a curator and that in such cases, a new annotation was asserted with the new evidence code rather than simply upgrading the evidence code from IEA to some other code, thus preserving the IEA annotations in Gramene that are produced by the Ensembl analysis pipeline [38].

There are many different metrics that have been used to evaluate the quality of predicted functional annotations. For the maize B73 GOMAP [12] annotation assessment, we used a modified version of the hierarchical evaluation metrics originally introduced in [39] because they were simple, clear, and part of an earlier attempt at unifying and standardizing GO annotation comparisons [40]. In the meantime, [41] published an approach for evaluating different metrics showing differences among the robustness of different approaches to quality assessment. Here we used the SimGIC2 and Term-centric Area Under Precision-Recall Curve (TC-AUCPCR) metrics recommended by [41]. We also evaluated with the $\mathrm{F}_{\max }$ metric, because it is very widely-used (e.g., by [10]), but according to [41] it is actually a flawed metric. Results of the quality assessments for the 10 genomes where a Gold Standard was available are shown in Table III and Figure S1. While evaluation values differ between metrics and the scores are not directly comparable, a few consistent patterns emerge: GOMAP annotations are almost always better than Gramene and Phyotzome annotations in the Cellular Component and Molecular Function aspect, with the only three exceptions being the Molecular Function aspect for Triticum aestivum using the TCAUCPCR and the $\mathrm{F}_{\max }$ metric and the Cellular Component aspect for Medicago truncatula A17 using the $\mathrm{F}_{\max }$ metric. Conversely, GOMAP predictions achieve consistently lower quality scores in the Biological Process aspect with the exception of Brachypodium dystachion, Oryza sativa, and Sorghum bicolor with the TC-AUCPR metric. Generally, annotations that are better in one aspect are also better in the other two aspects (there are few cross-overs in Figure 9), but the ranking of annotations does not necessarily hold across metrics. The Phytozome annotation for Oryza sativa is an outlier in terms of its comparative quality, potentially because it is based on a modified structural annotations that differ substantially from the Gold Standard and the other annotations under comparison.

\section{Phylogenetic Tree Analyses}

With the comparative quality of gene function predictions in hand, we approached the question of whether the datasets could be used together for comparative func- 
bioRxiv preprint doi: https://doi.org/10.1101/2021.04.25.441366; this version posted May 24, 2021. The copyright holder for this preprint (which was not certified by peer review) is the author/funder, who has granted bioRxiv a license to display the preprint in perpetuity. It is made available under aCC-BY 4.0 International license.

Table I: Functional annotation sets generated by GOMAP. More information about each dataset including the source of the input to GOMAP can be found at the respective DOI.

\begin{tabular}{|c|c|c|c|}
\hline Species & Germplasm/Line & Assembly/Annotation & Dataset DOI \\
\hline Arachis hypogaea & Tifrunner & Arachis hypogaea assembly 1.0 & [14] \\
\hline Brachypodium distachyon & $\mathrm{Bd} 21$ & Bd21.v3.1.r1 & {$[15]$} \\
\hline Cannabis sativa & Hemp & NCBI Cannabis sativa GCA_900626175.1 & {$[16]$} \\
\hline Glycine $\max$ & Williams 82 & Joint Genome Institute (JGI) Wm82.a4.v1 & {$[17]$} \\
\hline Gossypium raimondii & Cotton D & Gossypium raimondii JGI v2.1 & {$[18]$} \\
\hline Hordeum vulgare & - & IBSC_PGSB_r1 & {$[19]$} \\
\hline Medicago truncatula & R108_HM340 & R108: v1.0 & {$[20]$} \\
\hline Medicago truncatula & A17_HM341 & Mt4.0v2 & {$[21]$} \\
\hline Oryza sativa & japonica & IRGSP 1.0 & {$[22]$} \\
\hline Phaseolus vulgaris & G19833 & DOE-JGI and USDA-NIFA annotation 2.0 & {$[23]$} \\
\hline Pinus lambertiana & Sugar Pine & TreeGenesDB sugar pine assembly v1.5 & {$[24]$} \\
\hline Sorghum bicolor & BTx623 & BTx623.v3.0.1.r1 & {$[25]$} \\
\hline Triticum aestivum & Chinese Spring & IWGSC RefSeq 1.1 & {$[26]$} \\
\hline Vigna unguiculata & IT97K-499-35 & JGI annotation v1.1 & {$[27]$} \\
\hline Zea mays ${ }^{*}$ & Mo17 & Zm-Mo17-REFERENCE-CAU-1.0 & {$[28]$} \\
\hline Zea mays ${ }^{*}$ & PH207 & Zm-PH207-REFERENCE_NS-UIUC_UMN-1.0 & {$[29]$} \\
\hline Zea mays ${ }^{*}$ & W22 & Zm-W22-REFERENCE-NRGENE-2.0 Zm00004b.1 & {$[30]$} \\
\hline Zea mays ${ }^{*}$ & $\mathrm{~B} 73$ & RefGen_V4 Zm00001d.2 & {$[31]$} \\
\hline
\end{tabular}

Latest overview at https://dill-picl.org/projects/gomap/gomap-datasets/

${ }^{*}$ Previously published in [9].

tional analysis across all genomes. As a step in that direction, we began work toward understanding the degree to which trees built based on gene functions would agree with known, well-documented evolutionary relatedness patterns. We constructed and neighbor-joining and parsimony trees of the 18 plant genomes, and visulized them using iTOL [42], the two tree topologies, rooted at $P$. lambertiana, were compared to one another and to the topology of the expected tree (Figure 2). For both the neighbor-joining (Figure 3a) and parsimony trees (Figure $3 \mathrm{~b}$ ), one common difference is noted: $S$. bicolor is not at the base of the $Z$. mays clade as expected, and is clustered with $B$. distachyon instead. Notable differences between the neighbor-joining and parsimony tree are the following: $C$. sativa appears at the base of the eudicots instead of $G$. raimondii in the neighbor-joining tree, while $G$. raimondii is grouped with $A$. hypogaea and $C$. sativa is grouped with $G$. $\max$ in the parsimony tree. Second, O. sativa was expected to be at the base of the BOP clade, but appears at the base of $Z$. mays in the neighbor-joining tree, but at the base of all angiosperms in the parsimony tree. Differences among relationships within the $Z$. mays clade constaining B73, PH207, W22, and Mo17 were disregarded given the high degree of similarity across annotation sets and the fact that these relationships are not clear given the complex nature of within-species relationships

Due to differences between the function-based dendrograms and the expected tree, jackknifing analysis was carried out by removing terms (columns in underlying datasets) to determine the degree to which the underlying datasets support specific groupings based on functional term assignments. This analysis was carried out for both neighbor-joining and parsimony trees. First, trees were generated by omitting $5 \%$ then $10 \%$, then $15 \%$ on up to $95 \%$ of the dataset to determine the threshhold at which the tree topologies deviated from those generated using the full dataset. That threshold was at $45 \%$; therefore we used trees generated with $40 \%$ of the data removed for reporting branch support for the topology (Figure 3). Comparing the two trees, the topologies were similar at jackknife values up to $40 \%$ but the support values for parsimony were comparatively lower. Based on this robustness for neighbor-joining treebuilding in general, we carried out all subsequent analyses using neighbor-joining treebuilding methods.

To map the source of discrepancies to specific gene annotation sets, we generated various neighbor-joining trees excluding one genome each time, an additional tree with both Medicago genomes excluded, and another with all $Z$. mays genomes excluded. To exemplify this, see the monocot clade in Figure 2 and the lower (monocot) clade in Figure 3a. When the neighbor-joining tree was generated, two species are misplaced: $S$. bicolor and $O$. sativa. As shown in Figure 4a, removal of $O$. sativa corrects one error (itself) but does not correct the errant grouping of $S$. bicolor with $B$. distachyon. In $4 \mathrm{~b}$, it is shown that the removal of $S$. bicolor corrects the errant grouping of itself and $B$. distachyon, but $O$. sativa placement remains incorrect. However, as shown in $4 \mathrm{~d}$, the removal of $B$. distachyon generates a tree where all relationships are in agreement with known species-level relationships. (Note 
bioRxiv preprint doi: https://doi.org/10.1101/2021.04.25.441366; this version posted May 24, 2021. The copyright holder for this preprint (which was not certified by peer review) is the author/funder, who has granted bioRxiv a license to display the preprint in perpetuity. It is made available under aCC-BY 4.0 International license.

\section{a. Workflow Overview}

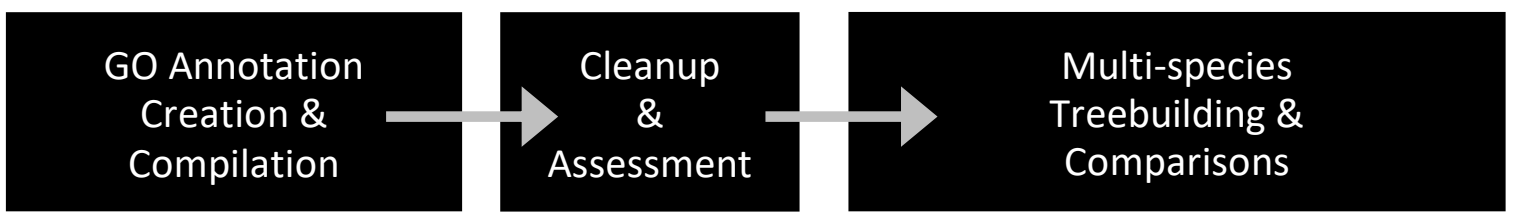

b. Workflow Detail

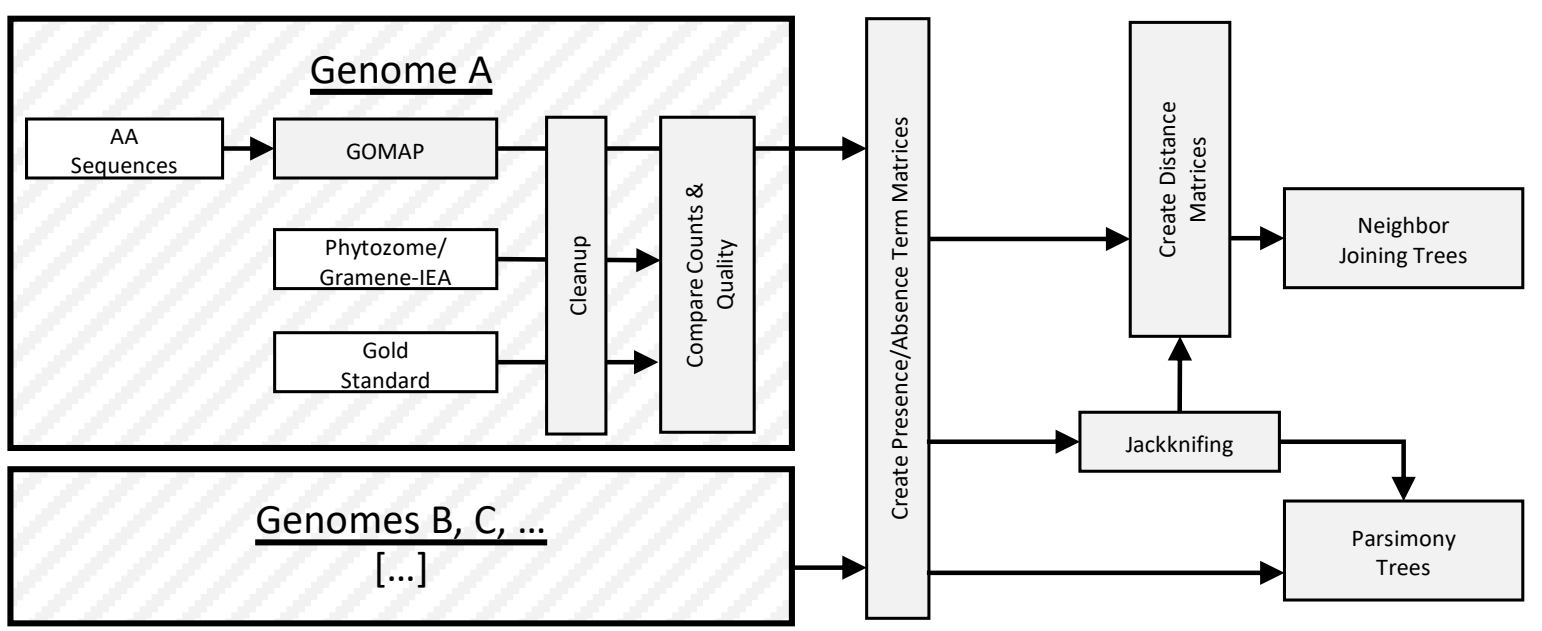

Figure 1: Data workflow schema. The workflow overview is shown in panel 'a' with steps represented as black boxes and the flow of information and processes indicated by arrows. Details are shown in panel 'b' where the upper large hatched box shows process detail for a single genome and the lower hatched box represents additional genomes for which the details of processing are identical. White boxes represent input datasets. Arrows indicate the flow of information and processes.

well: all individual annotation sets were progressively removed, not just these three shown in the example.)

With this observation in hand, we sought to determine the minimum number of genomes that could be removed to create a tree that matched the expected tree topology. The removal of the three genomes was required to generate function-based trees consistent with known phylogenetic relationships. They are C. sativa, G. $\max$, and B. distachyon (Figure 5). Jackknifing analysis was also carried out for this dataset with support shown. Branch support is generally higher than that for the full dataset (i.e., branch support is higher in Figure 5 than in Figure 3a).

\section{Potential Causes of Unexpected Groupings}

As a first step in investigating whether and how the comparative quality of assemblies and annotation sets underlying the predicted gene function datasets could explain discrepancies between known evolutionary relationships and those resulting from comparative analysis of genome-wide gene function predictions, we assessed the quality of each genome assembly and structural annotation set using GenomeQC [43]. Assembly quality (Table

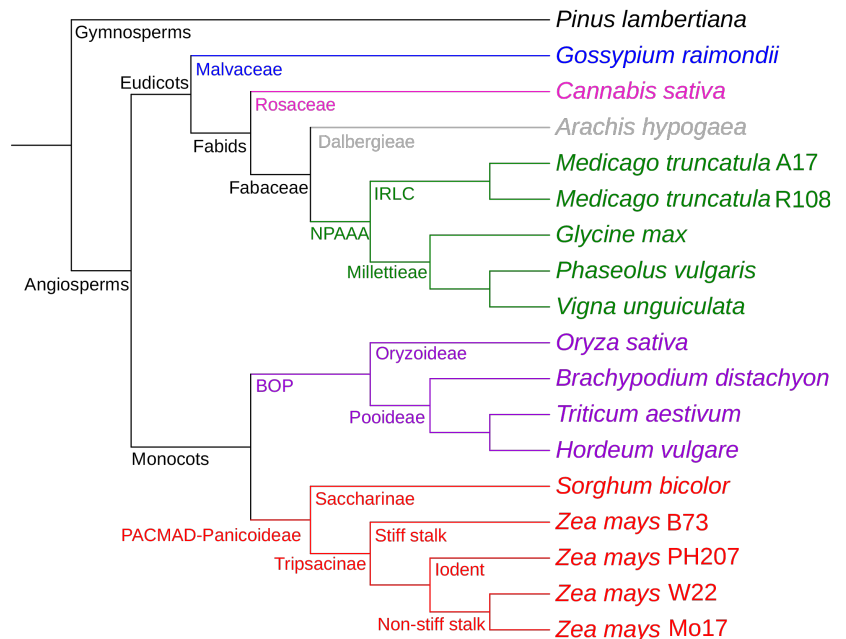

Figure 2: Phylogenetic relationships among species. Cladogram is rooted by the gymnosperm Pinus lambertiana (black). Among angiosperms, eudicots clades include Malvaceae (blue), Rosaceae (magenta), Dalbergieae (grey), and NPAAA (green). Monocots include members of the BOP (purple) and PACMAD-Panicoideae (red) clades. 
bioRxiv preprint doi: https://doi.org/10.1101/2021.04.25.441366; this version posted May 24, 2021. The copyright holder for this preprint (which was not certified by peer review) is the author/funder, who has granted bioRxiv a license to display the preprint in perpetuity. It is made available under aCC-BY 4.0 International license.
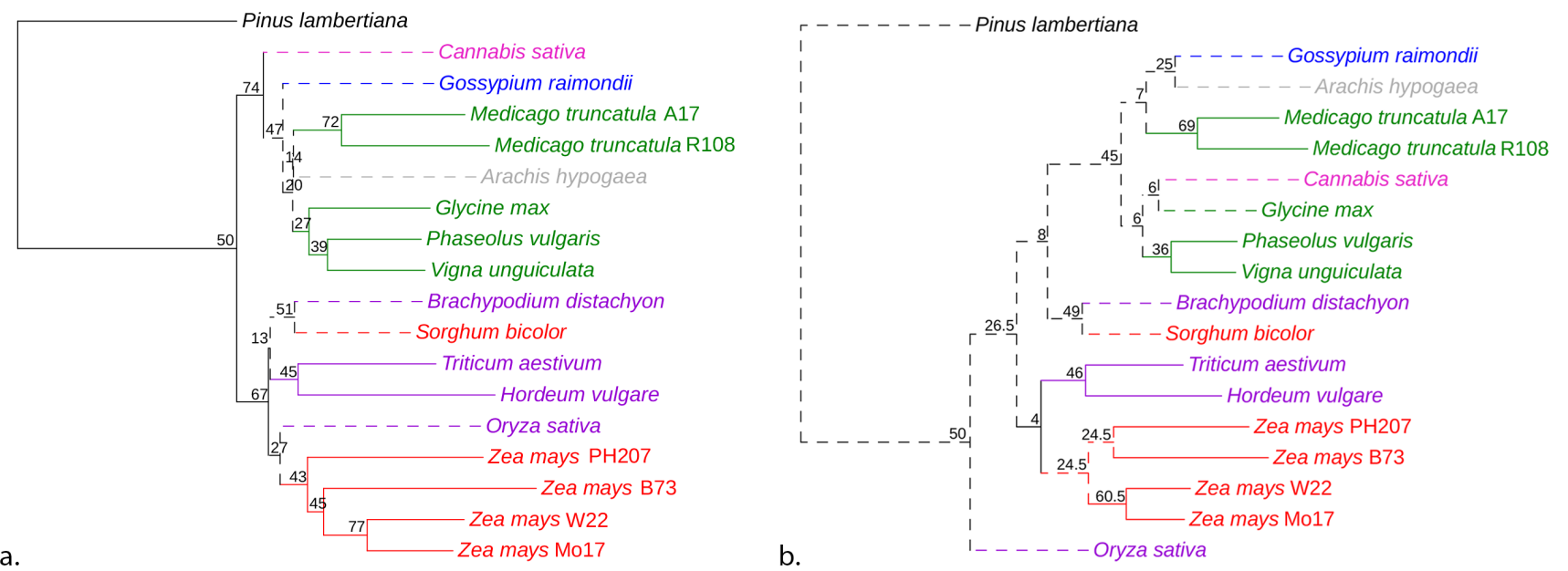

Figure 3: Neighbor-joining and parsimony trees. Phylograms are colored and rooted as described in Figure 1. For both neighbor-joining (a) and parsimony (b), node values represent the jackknifing support values derived by removing $40 \%$ of GO terms in the dataset. Dashed lines mark deviations from known phylogenetic relationships. Tree scales are shown above each, with NJ showing distances and parsimony showing changes in character state.

IV), structural annotation measures of quality (Table V), and proportion of single-copy BUSCOS (short for benchmarking universal single-copy genes; [44]) (Figures 8 and 9 , respectively) can be compared across assembly and annotation products. As shown in Table IV, among the genomes available via GenomeQC, G. $\max$ and B. distachyon have comparatively low values for percent of the genome that is useful (as calculated based on scaffold number and scaffold size relative to published genome sizes). In addition, as shown in Figure 7, the number of gene models $<200$ base pairs in length is comparatively high for $G$. max. Compounding these issues, for G. max, structural annotations for BUSCOS are duplicated for many G. max genes, which is to be expected for a hexaploid genome. Because the method used for tree construction collapses all GO terms to presence or absence rather than taking the number of instances of a particular term into account, it is unclear how the duplicate nature of the genome affects these analyses.

In the case of $C$. sativa, the fact that the line sequenced is not inbred may account for misplacement in the function-based dendrograms. This means that to generate an assembly, there are likely regions where alleles are not aligned, which would inflate the length of the assembly. Indeed, the comparatively low-quality assembly for Cannabis genome has been noted by others [45], and our preliminary investigations indicate that the assembly length is in fact longer than expected based on $\mathrm{C}$-values for genome sizes reported previously [46]. In addition, we found $184 \mathrm{GO}$ terms missing from $C$. sativa that were present in the rest of the eudicots, and 93 additional terms that were only in $C$. sativa but none of the other eudicots in our study. This finding could con- firm the poor quality of the $C$. sativa genome used in our dataset. More efforts to determine in detail the causes of these discrepancies are currently underway.

\section{DISCUSSION}

In this study, we used the GOMAP pipeline to produce whole-genome GO annotations for eighteen genome assembly and annotation sets from fourteen plant species [9]. Assessments of the number of terms predicted as well as the quality of predictions (based on F-score) indicate that GOMAP functional prediction datasets cover more genes, produce more predictions per gene, and are of similar quality to smaller prediction datasets produced by other systems, thus supporting the notion that these high-coverage datasets are a useful addition for researchers who are interested in genome-level analyses, including efforts aimed at prioritizing candidate genes for downstream analyses. Given that we can now produce high-quality, whole genome functional annotations for plants in a straightforward way, we intend to produce more of these over time (indeed we recently annotated Vitis vinifera Pinot Noir grape [47], Brassica rapa (doi in process), Musa acuminata [48], Theobroma cacao [49], Solanum lycopersicum [50], and Solanum pennellii [51]).

With eighteen genome functional annotations in hand, we sought to determine whether and how researchers could use multispecies GO annotation datasets to perform comparative functional genomics analyses. As a first step in that direction and a proof of concept, we adapted phylogenetic tree-building methods to use the gene function terms assigned to genes represented in 
Tree scale: 0.1

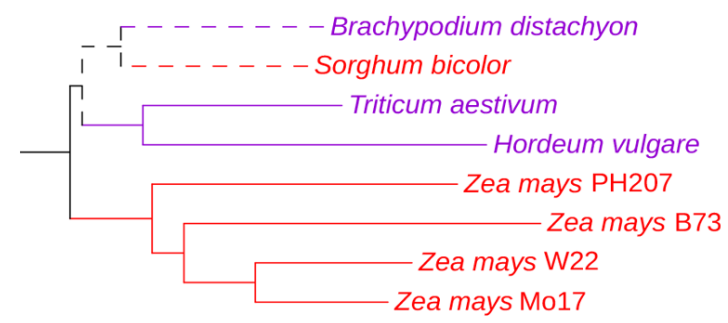

a.

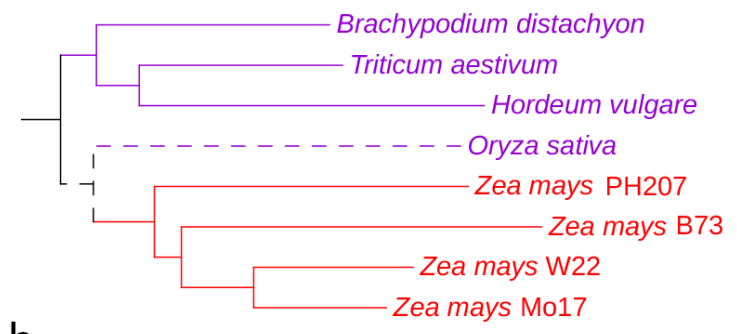

b.

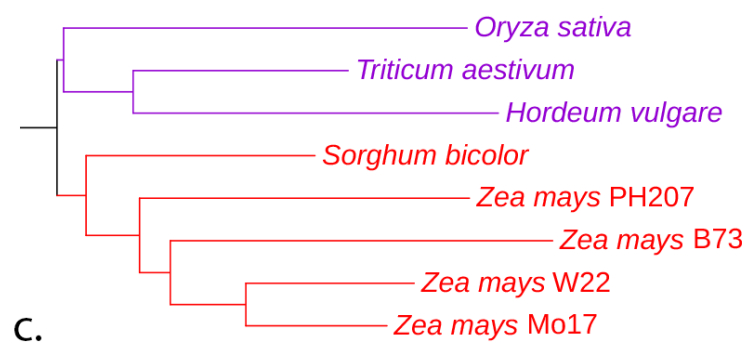

Figure 4: Restoring monocot relationships. Phylograms are colored and rooted as described in Figure 1. Dashed lines mark deviations from known phylogenetic relationships. Monocot topology changes with removal of a single species: a) O. sativa, b) S. bicolor, and c) B. distachyon. Tree scale is shown above.

genomes to build dendrograms of functional relatedness and hypothesized that if the functions were comparable across species, the resulting trees would closely match evolutionary relationships. To our delight and surprise, the neighbor-joining and parsimony trees (Figure 3) did resemble known phylogenies, but were not exact matches to broadly accepted phylogenetic relationships.

After removing the minimum number of genomes that resulted in restoration of the expected evolutionary relationships, we found that the individual species that may be responsible for the discrepancies observed in Figure 3 were $C$. sativa, G. $\max$, and B. distachyon. We hypothesize in a general way that the following reasons could account for these errant relationships:

1) Quality of sequencing and coverage assembly: genomes of similarly high sequence coverage that have excellent gene calling would be anticipated to create the

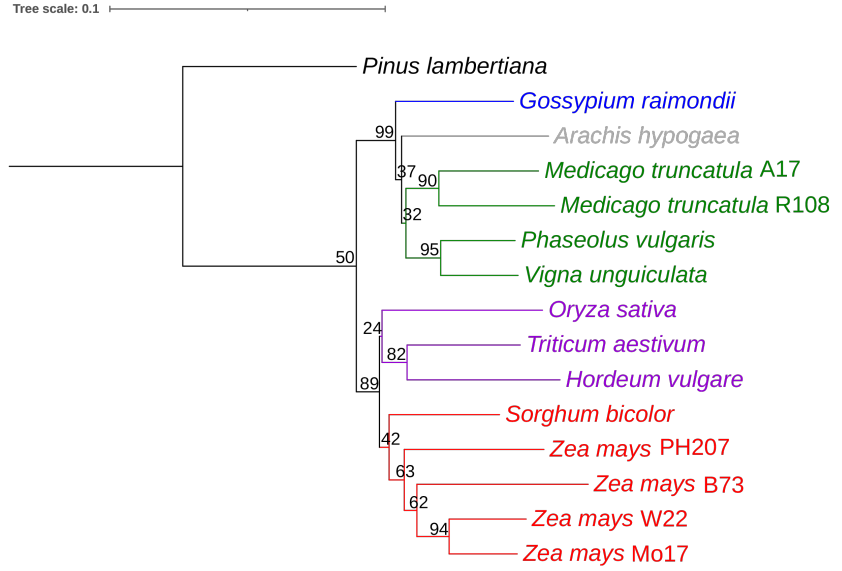

Figure 5: Restoring known phylogentic relationships to the NJ tree via removal of a minimal number of species. Phylograms are colored and rooted as described in Figure 1. Node values represent the jackknifing support values derived by removing $40 \%$ of GO terms in the dataset. 3 genomes have been removed: C. sativa, G. max, and B. distachyon. Tree scale is shown above.

best source for functional annotation. Genomes of comparatively lower, or different, character would be anticipated to mislead treebuilding and other comparative genomics approaches.

2) Reference guided assembly: if one genome is used to guide the assembly and annotation of another genome, some similarities may result naturally due to the inheritance of information.

3) Shared selected or natural traits: species that have been selected for, e.g., oilseeds may share genes involved in synthesis of various oils. Other shared traits would be anticipated to cause similarities for species with those. shared traits.

For the species noted in this paper as misleading treebuilding based on whole-genome gene function, we find that the most likely cause of discrepancies between phylogenetic trees and those inferred from gene functions is the simplest: differences in quality of input sequence assemblies and gene structure annotations. The particular differences are our current focus for investigation and are anticipated to result in updates and additions to this manuscript.

In conclusion, we have demonstrated that the GOMAP system produces datasets can be used together for comparative functional genomics analyses if the datasets are derived from comparably high-quality assemblies and gene annotations. We look forward not only to developing systems to support comparative functional genomics tools, but also to seeing the tools other research groups will develop to approach these datasets for use to formulate useful comparative functional genomics hypotheses. 


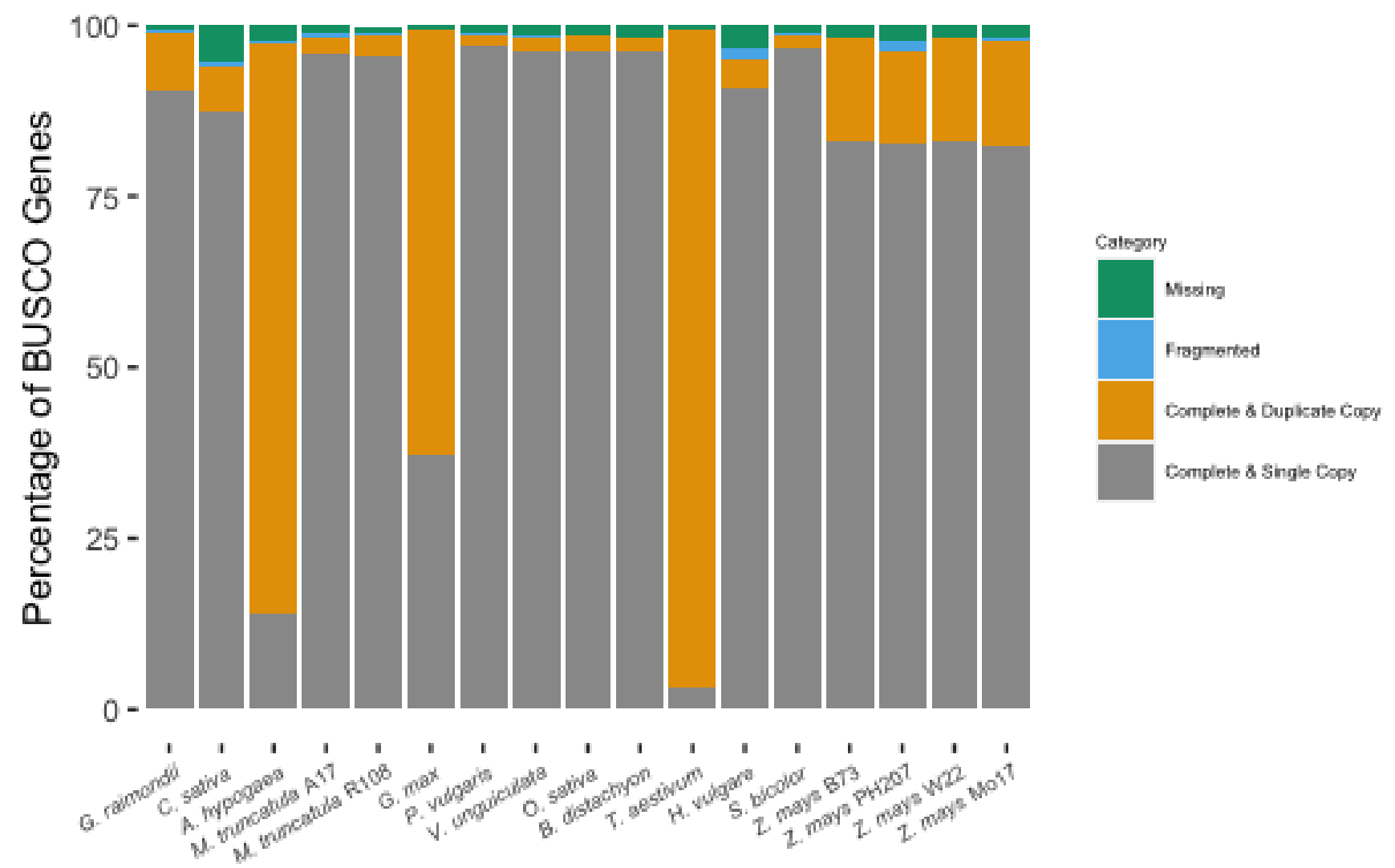

Genomes

Figure 6: Assembly BUSCO plot generated using GenomeQC. Genomes analyzed are shown across the X-axis, and are ordered to match the occurrence of species shown in Figure 2. Percentage of BUSCO genes across four gene categories are stacked, with each adding up to 100 percent (Y-axis). Complete and single-copy genes are shown in grey, complete and duplicated copies in orange, fragmented copies in blue, and missing are shown copies in green.

\section{METHODS}

\section{A. Acquiring Input Datasets}

For each of the 18 genomes listed in Table I, information on how to access input annotation products are listed in the DOI shown. For each, one representative translated peptide sequence per protein coding gene was selected and used as the input for GOMAP. Unless the authors of the genome provided a set of representative sequences designated as canonical, we chose the longest translated peptide sequence as the representative for each gene model. Non-IUPAC characters and trailing asterisks $(*)$ were removed from the sequences, and headers were simplified to contain only non-special characters. The corresponding script for each dataset can be found at the respective DOI that required these changes. Based on this input, GOMAP yielded a functional annotation set spanning all protein-coding genes in the genome. Using the Gene Ontology version releases/2020-10-09, this functional annotation set was cleaned up by removing duplicates, annotations with modifiers, and obsolete GO terms. Any terms containing alternative identifiers were merged to their respective main identifier, which uncovered a few additional duplicates, which were also removed. Table SI shows the number of annotations removed from each dataset produced.

To compare the quality of GOMAP predictions to currently available functional predictions from Gramene and Phytozome, we downloaded IEA annotations from Gramene (version 63, [36], https://www.gramene.org/) and Phytozome (version 12, [37], https://phytozome.jgi.doe.gov/) for each species with functional annotations of the same genome version. These datasets were cleansed of duplications and redundancies. Similarly cleaned non-IEA annotations from Gramene served as the Gold Standard wherever they were available. More detailed information on how we accessed these datasets can be found at https: //github.com/Dill-PICL/GOMAP-Paper-2019.1/ $\mathrm{blob} / \mathrm{master} /$ data/go_annotation_sets/README.md. 


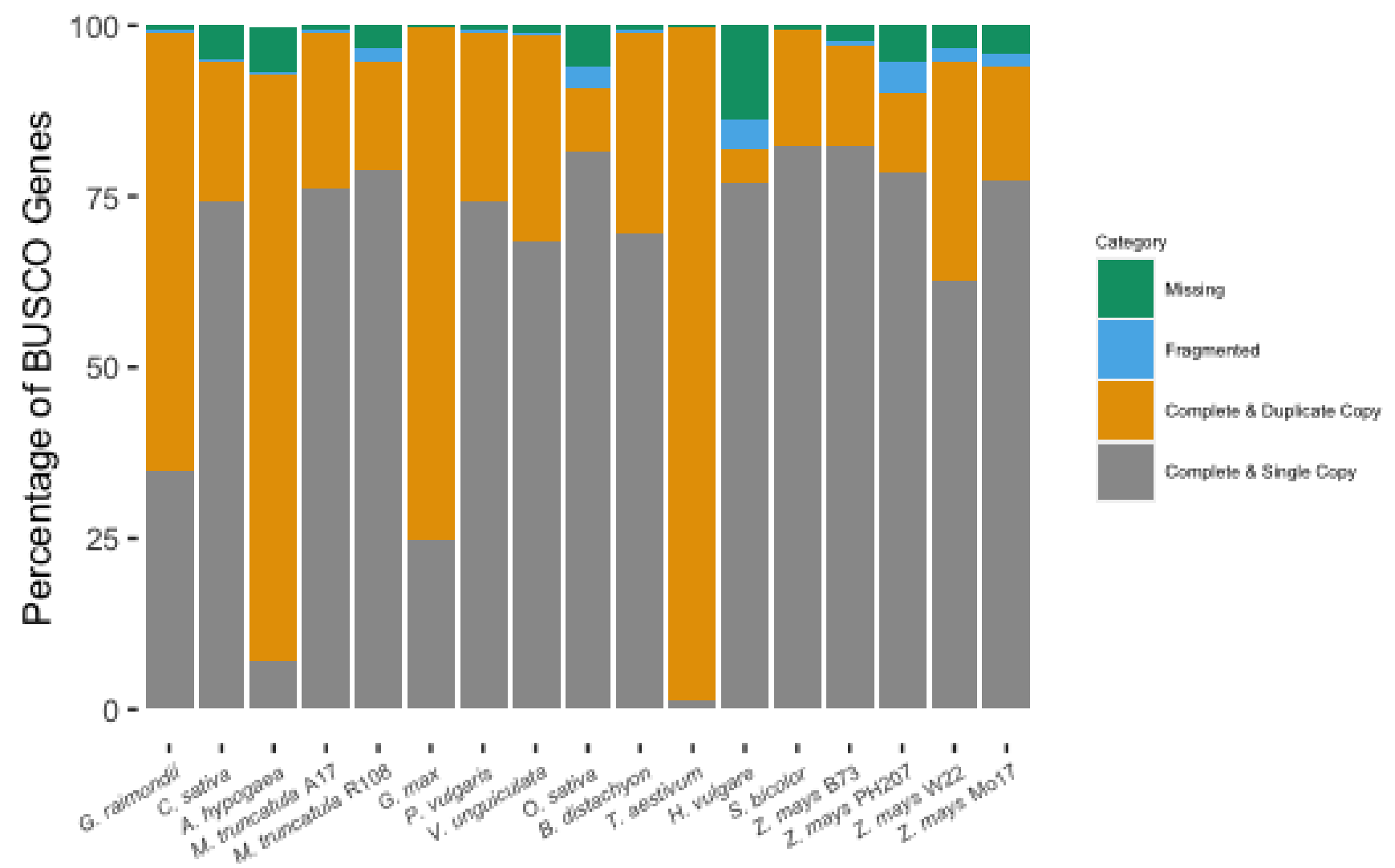

Genomes

Figure 7: Annotation BUSCO plot generated using GenomeQC. Genomes analyzed are shown across the X-axis, and are ordered to match the occurrence of species shown in Figure 2. Percentage of BUSCO genes across four gene categories are stacked, with each adding up to 100 percent (Y-axis). Complete and single-copy genes are shown in grey, complete and duplicated copies in orange, fragmented copies in blue, and missing are shown copies in green.

\section{B. Quantitative and Qualitative Evaluation}

The number of annotations in each cleansed dataset was determined and related to the number of protein coding genes (based on transcripts in the input FASTA file). This was done for separately for each GO aspect as well as in total (see Table II).

The ADS software version published in [41] is available from https://bitbucket.org/plyusnin/ads/. We used version b6309cb (also included in our code as a submodule) to calculate SimGIC2, TC-AUCPCR, and $\mathrm{F}_{\max }$ quality scores. To provide the information content required for the SimGIC2 metric, the Arabidopsis GOA from https://www.ebi.ac.uk/GOA/ arabidopsis_release was used in version 2021-02-16.

\section{Cladogram Construction}

For clustering, we first collected all GO terms annotated to any gene in each genome into a list and re- moved the duplicates, yielding a one-dimensional set of GO terms for each genome $(T)$. Next, we added all ancestor terms for each term in this set $T$ and once again removed the duplicates, yielding a set $S$. These sets with added ancestors served as a starting point of our tree-building analyses: pairwise distances between the genomes were calculated using the Jaccard distance as a metric of the dissimilarity between any two sets $a$ and $b$.

$$
d_{a b}=1-\frac{\left|S_{a} \cap S_{b}\right|}{\left|S_{a} \cup S_{b}\right|}
$$

Then a neighbor-joining tree was constructed on the pairwise distance matrix using PHYLIP [32]. Additionally, term sets $S$ of all genomes were combined into a binary matrix (with rows corresponding to genomes and columns corresponding to GO terms, values of 0 or 1 indicating whether a term is present or absent in the given set). PHYLIP pars was used to construct a parsimony tree from this binary matrix.

$P$. lambertiana, a gymnosperm, was included in the dataset as an outgroup to the angiosperms to separate 
between the monocot and eudicot plants. iTOL [52] was used to visualize the trees using their Newick format, and root them at $P$. lambertiana. Moreover, a cladogram representing the known phylogeny of the included taxa was created by hand based on known evolutionary relationships $[53,54,55,56,57]$. This was used to compare the generated phylogenetic relationship based on functional similarity with the evolutionary relationships of the plant genomes.

Jackknifing analysis was carried out for both parsimony and neighbor-joining trees to assess the support for each clade based on the proportion of jackknife trees showing the same clade. To this end, $40 \%$ of the terms in $T$ were randomly removed, ancestors of the remaining terms were added and trees constructed as above. The majority rule consensus tree of 100 individual trees was calculated with the jackknife values represented on each branch. The tree was then visualized using iTOL using its Newick format, and rooted again at P. lambertiana.

\section{Genome Quality Evaluation}

Genome size was estimated from the C-values obtained from the Plant DNA C-values data resource from the Kew Database (https://cvalues.science.kew.org). The mean C-value for a given species was used for calculating genome size estimates in base pairs (bp) using the method of [58]. In brief,

$$
\text { Genome size }(\mathrm{bp})=\mathrm{C} \text {-value }(\mathrm{pg}) * 0.978 \times 10^{9} \frac{\mathrm{bp}}{\mathrm{pg}}
$$

The estimated genome size (listed in Table IV) was used as an input for GenomeQC (https://genomeqc.maizegdb.org/) [43] to calculate quality metrics. For genomes that were too large to submit through the GenomeQC webtool or had missing exon information, modified scripts of those found in GitHub of GenomeQC (https://github.com/HuffordLab/GenomeQC, commit e6140ee) were applied to calculate the assembly and structural annotation metrics in Table IV and $\mathrm{V}$. BUSCO version 5.0.0 [59] was used to calculate the assembly and annotation BUSCO scores, shown in Figures 6 and 7 . The input for assembly BUSCO scores were chromosome sequences, whereas inputs were transcript/mRNA/CDS sequences for the annotation BUSCO scores. For the lineage parameter, the lineage datasets used were as follows: Eudicots for C. sativa and G. raimondii, Fabales for A. hypogaea, M. truncatula A17 and R108, P. vulgaris, G. max, and V. unguiculata, and Poales for B. distachyon, O. sativa, T. aestivum, $H$. vulgare, S. bicolor and Z. mays B73, Mo17, W22 and PH207.

\section{AVAILABILITY OF SOURCE CODE AND SUPPORTING DATA}

All used data and source code are freely available at https://github.com/Dill-PICL/GOMAP-Paper-2019. 1 under the terms of the MIT license. All software requirements and dependencies are packaged into a Singularity container so no other setup is required. We will provide a DOI through Zenodo for the final version of the manuscript after reviews and corrections are incorporated.

An up-to-date list of all available annotation sets can be found at https://dill-picl.org/projects/gomap/ gomap-datasets/.

\section{DECLARATIONS}

\section{A. Competing Interests}

The author(s) declare that they have no competing interests.

\section{B. Funding}

This work has been supported by the Iowa State University Plant Sciences Institute Faculty Scholars Program to CJLD, the Predictive Plant Phenomics NSF Research Traineeship (\#DGE-1545453) to CJLD (CFY is a trainee), and IOW04714 Hatch funding to Iowa State University.

\section{Author's Contributions}

LF, DP, DFY, KC, HAD, PJ, DCS, HV, and KW generated annotations for plants as described in this paper. DP and CJLD co-conceived the idea for phylogenetic analysis. LF worked with DP to create dendrograms and compare those to phylogenetic trees. LF carried out assembly and annotation metric comparisons. LF, DP, and CJLD wrote the manuscript. All authors read, offered suggestions to improve, and approved the final copy of the manuscript.

\section{ACKNOWLEDGEMENTS}

Thanks to Steven Cannon for help to understand phylogenetic relationships among eudicots and helpful discussions and to Toby Kellogg for discussions and ideas on how to consider the data. Thanks to Nancy Manchanda for reviewing documentation and for checking genome versions used as input for GenomeQC. Thanks to Darwin Campbell who guided the deposition of datasets with CyVerse for release and DOI assignment. 
bioRxiv preprint doi: https://doi.org/10.1101/2021.04.25.441366; this version posted May 24, 2021. The copyright holder for this preprint (which was not certified by peer review) is the author/funder, who has granted bioRxiv a license to display the preprint in perpetuity. It is REFERENCES made available under aCC-BY 4.0 International license.

\section{AUTHORS' INFORMATION}

KW created the GOMAP system during his time as a graduate student at Iowa State University. LF, DP, CFY, $\mathrm{KC}, \mathrm{HV}$, and PJ are currently graduate students. HAD and DCS are undergraduate students. Each graduate and undergraduate student annotated at least one genome over the course of a research rotation lasting no more than one semester. CJLD coordinated research activities and manuscript preparation.

\section{References}

[1] Michael Ashburner et al. "Gene Ontology: tool for the unification of biology". In: Nature genetics 25.1 (May 2000), pp. 25-29. ISSN: 1061-4036. DOI: $10.1038 / 75556$. URL: https: //www .ncbi.nlm.nih.gov/pmc/articles/ PMC3037419/ (visited on 03/12/2021).

[2] The Gene Ontology Consortium et al. "The Gene Ontology resource: enriching a GOld mine". en. In: Nucleic Acids Research 49.D1 (Jan. 2021), pp. D325-D334. ISSN: 0305-1048, 1362-4962. DOI: 10 . 1093 / nar / gkaa1113. URL: https : / / academic . oup . com/nar / article/49/ D1/D325/6027811 (visited on 03/12/2021).

[3] Minoru Kanehisa et al. "KEGG: integrating viruses and cellular organisms". In: Nucleic Acids Research 49.D1 (Oct. 2020), pp. D545-D551. DOI: 10 . $1093 /$ nar / gkaa970. URL: https : / / doi . org / 10 . 1093 / nar / gkaa970.

[4] Oliver Thimm et al. "mapman: a user-driven tool to display genomics data sets onto diagrams of metabolic pathways and other biological processes". In: The Plant Journal 37.6 (Mar. 2004), pp. 914-939. DOI: 10.1111/ j.1365-313x.2004.02016.x. URL: https://doi.org/ 10.1111/j.1365-313x.2004.02016.x.

[5] D. Binns et al. "QuickGO: a web-based tool for Gene Ontology searching". In: Bioinformatics 25.22 (Sept. 2009), pp. 3045-3046. DOI: 10.1093/bioinformatics/ btp536. URL: https : / / doi . org / 10 . 1093 / bioinformatics/btp536.

[6] Iris Tzafrir et al. "Identification of Genes Required for Embryo Development in Arabidopsis". en. In: Plant Physiology 135.3 (July 2004). Publisher: American Society of Plant Biologists Section: GENOME ANALYSIS, pp. 1206-1220. ISSN: 0032-0889, 1532-2548. DOI: 10. 1104/pp.104.045179. URL: http://www.plantphysiol. org/content/135/3/1206 (visited on 03/12/2021).

[7] Ana Conesa and Stefan Götz. "Blast2GO: A Comprehensive Suite for Functional Analysis in Plant Genomics". en. In: International Journal of Plant Genomics 2008 (Apr. 2008), pp. 1-12. ISSN: 1687-5370, 1687-5389. DOI: 10 . $1155 / 2008 / 619832$. URL: https : / / www . hindawi . com / journals / ijpg / 2008/619832/ (visited on $03 / 12 / 2021$ ).

[8] Seung Yon Rhee and Marek Mutwil. "Towards revealing the functions of all genes in plants". In: Trends in Plant Science 19.4 (Apr. 2014), pp. 212-221. ISSN: 1360-1385. DOI: $10.1016 / \mathrm{j}$.tplants . 2013 .10 . 006. URL: https : / / www . sciencedirect . com / science / article / pii / S1360138513002343 (visited on 03/12/2021).
[9] Kokulapalan Wimalanathan and Carolyn J. LawrenceDill. "Gene Ontology Meta Annotator for Plants (GOMAP)". In: bioRxiv; Plant Methods (in press) (2021). DOI: 10 . 1101/809988. eprint: https : / / www . biorxiv . org / content / early / 2021 / 02 / 25 / 809988 . full . pdf. URL: https: //www . biorxiv . org/content/ early/2021/02/25/809988.

[10] Naihui Zhou et al. "The CAFA challenge reports improved protein function prediction and new functional annotations for hundreds of genes through experimental screens". In: Genome Biology 20.1 (Nov. 2019). DOI: 10.1186/s13059-019-1835-8. URL: https://doi.org/ $10.1186 / \mathrm{s} 13059-019-1835-8$.

[11] URL: https://www.biofunctionprediction.org.

[12] Kokulapalan Wimalanathan et al. "Maize GO Annotation-Methods, Evaluation, and Review (maizeGAMER)". In: Plant Direct 2.4 (Apr. 2018), e00052. ISSN: 24754455 . DOI: 10 . $1002 /$ pld3 . 52. URL: http : //doi.wiley.com/10.1002/pld3.52.

[13] Chengsheng Zhu et al. "Functional Basis of Microorganism Classification". en. In: PLOS Computational Biology 11.8 (Aug. 2015). Publisher: Public Library of Science, e1004472. ISSN: 1553-7358. DOI: 10.1371/journal. pcbi . 1004472. URL: https : / / journals . plos . org / ploscompbiol / article? id=10.1371/ journal . pcbi . 1004472 (visited on 03/12/2021).

[14] Dennis Psaroudakis and Carolyn Lawrence-Dill. GOMAP Peanut IPGI 1.0. 2019. DOI: 10.25739/CHABOE35. URL: http : / / datacommons . cyverse . org / browse/iplant/home/shared/commons_repo/curated/ Carolyn_Lawrence_Dill_GOMAP_Peanut_Tifrunner . IPGI.1.0_August_2019.r1.

[15] Kokulapalan Wimalanathan and Carolyn LawrenceDill. GOMAP Bdistachyon.Bd21.v3.1.r1. 2019. DOI: 10 . 25739 / DW2T - 3G82. URL: http : / / datacommons . cyverse .org/browse/iplant/home/shared/commons_ repo / curated / Carolyn _ Lawrence _ Dill _ GOMAP _ Bdistachyon.Bd21.v3.1_November_2019.r1.

[16] Kevin Chiteri and Carolyn Lawrence-Dill. GOMAP_Cannabis_sativa_NCBI-cs10_January_2020. 2020. DOI: 10 . 25739 / AB9Z - 2Z86. URL: http : //datacommons . cyverse . org/browse/iplant/home/ shared / commons_repo/ curated / Carolyn_Lawrence _ Dill_GOMAP_Cannabis_NCBI-cs10_January_2020.r1.

[17] Dennis Psaroudakis and Carolyn Lawrence-Dill. GOMAP Soybean JGI-Wm82.a4.v1. 2019. DOI: 10 . 25739 / 59EC-1719. URL: http : / / datacommons . cyverse .org/browse/iplant/home/shared/commons_ repo / curated / Carolyn _ Lawrence _ Dill _ GOMAP _ Soybean_JGI-Wm82.a4.v1_April_2019.r1.

[18] Parnal Joshi and Carolyn Lawrence-Dill. GOMAP Gossypium raimondii JGI v2.1. 2020. DOI: 10.25739/ A13T - ZH47. URL: http : / / datacommons . cyverse . org / browse / iplant / home / shared / commons_repo / curated/Carolyn_Lawrence_Dill_GOMAP_Gossypium _ raimondii_JGI_v2.1_January_2020.r1.

[19] Colleen Yanarella and Carolyn Lawrence-Dill. GOMAP Barley Reference Sequences IBSC_PGSB_r1. 2019. DOI: 10 . 25739 / ZVGV - 8E37. URL: http : / / datacommons . cyverse .org/browse/iplant/home/shared/commons_ repo / curated / Carolyn _ Lawrence _ Dill _ GOMAP _ Barley_IBSC_PGSB-1.0_May_2019.r1.

[20] Dennis Psaroudakis and Carolyn Lawrence-Dill. GOMAP Barrel Clover R108_HM340 v1.0. 2019. DOI: 
bioRxiv preprint doi: https://doi.org/10.1101/2021.04.25.441366; this version posted May 24, 2021. The copyright holder for this preprint (which was not certified by peer review) is the author/funder, who has granted bioRxiv a license to display the preprint in perpetuity. It is REFERENCES made available under aCC-BY 4.0 International license.

10. 25739 / 2SQC-J140. URL: http : / / datacommons . cyverse.org/browse/iplant/home/shared/commons_ repo / curated / Carolyn _ Lawrence _ Dill _ GOMAP _ BarrelClover_R108_HM340_v1.0_August_2019.r1.

[21] Dennis Psaroudakis and Carolyn Lawrence-Dill. GOMAP Barrel Clover A17_HM341 Mt4.Ov2. 2019. DOI: 10.25739/PY38-YB08. URL: http://datacommons . cyverse .org/browse/iplant/home/shared/commons_ repo / curated / Carolyn _ Lawrence _ Dill _ GOMAP _ BarrelClover_A17_HM341_Mt4.0v2_August_2019.r1.

[22] $\mathrm{Ha} \mathrm{Vu}$ and Carolyn Lawrence-Dill. GOMAP Rice Reference Sequences 2.0. 2019. DOI: 10 . 25739 / 53G0 J859. URL: http : / / datacommons . cyverse . org / browse/iplant/home/shared/commons_repo/curated/ Carolyn_Lawrence_Dill_GOMAP_Rice_ IRGSP - 1.0 _ April_2019.r2.

[23] Dennis Psaroudakis and Carolyn Lawrence-Dill. GOMAP Common Bean DOE-JGI and USDANIFA v2.0. 2019. DOI: 10.25739 / 1YWE - EW96. URL: http : / / datacommons . cyverse . org/browse/iplant / home / shared / commons _ repo / curated / Carolyn _ Lawrence_Dill_GOMAP_CommonBean_DOE - JGI - USDA NIFA.2.0_August_2019.r1.

[24] Colleen Yanarella and Carolyn Lawrence-Dill. GOMAP TreeGenesDB sugar pine assembly v1.5. 2020. DOI: 10. 25739 / JVS4 - XR88. URL: http : / / datacommons . cyverse .org/browse/iplant/home/shared/commons_ repo / curated / Carolyn _ Lawrence _ Dill _ GOMAP _ SugarPine_TreeGenesDB-1.5_January_2020.r1.

[25] Kokulapalan Wimalanathan and Carolyn LawrenceDill. GOMAP Sbicolor.BTx623.v3.0.1.r1. 2019. DOI: 10. 25739 / 4TYO - YE98. URL: http : / / datacommons . cyverse .org/browse/iplant/home/shared/commons_ repo / curated / Carolyn _ Lawrence _ Dill _ GOMAP _ Sbicolor.BTx623.v3.0.1_November_2019.r1.

[26] Dennis Psaroudakis and Carolyn Lawrence-Dill. GOMAP Wheat Reference Sequences 1.1. 2019. DOI: 10. 25739 / 65KF - JZ20. URL: http : / / datacommons . cyverse .org/browse/iplant/home/shared/commons_ repo/curated/Carolyn_Lawrence_Dill_GOMAP_Wheat_ RefSeq1.1_HC_December_2018.r1.

[27] Dennis Psaroudakis and Carolyn Lawrence-Dill. GOMAP Cowpea IT97K-499-35 JGI annotation v1.1. 2019. DOI: 10.25739 / CDX9 - WR97. URL: http : //datacommons . cyverse .org/browse/iplant/home / shared / commons_repo / curated / Carolyn_Lawrence _ Dill_GOMAP_Cowpea_JGI.v1.1_August_2019.r1.

[28] Kokulapalan Wimalanathan and Carolyn LawrenceDill. GOMAP Maize Zm-Mo17-REFERENCE-CAU-1.0 Zm00014a.1. 2019. DOI: 10 . 25739 / M634-CN58. URL: http : / / datacommons . cyverse . org/browse/iplant/ home / shared / commons _ repo / curated / Carolyn _ Lawrence _ Dill_GOMAP_maize . Mo17 . AGPv1_ April _ 2019.r1.

[29] Kokulapalan Wimalanathan and Carolyn LawrenceDill. GOMAP Maize Zm-PH207-REFERENCE_NSUIUC_UMN-1.0 Zm00008a.1. 2019. DOI: 10 . 25739 / DM9S-AA15. URL: http : //datacommons . cyverse .org/ browse/iplant/home/shared/commons_repo/curated/ Carolyn_Lawrence_Dill_GOMAP_maize . PH207 . UIUC_ UMN-1.0_April_2019.r1.

[30] Kokulapalan Wimalanathan and Carolyn LawrenceDill. GOMAP Maize Zm-W22-REFERENCENRGENE-2.0 Zm00004b.1. 2019. DOI: 10.25739/E4VA-
9F09. URL: http : / / datacommons . cyverse . org / browse/iplant/home/shared/commons_repo/curated/ Carolyn_Lawrence_Dill_GOMAP_maize. W22 . AGPv2 _ April_2019.r1.

[31] Kokulapalan Wimalanathan and Carolyn Lawrence-Dill. maize-GAMER Annotaions for maize.B73.AGPv4.r1. 2017. DOI: 10.7946/P2M925. URL: http : / / datacommons . cyverse . org/browse/iplant / home / shared / commons _ repo / curated / Carolyn _ Lawrence-Dill_maize-GAMER_maize.B73_RefGen_v4_ Zm00001d.2_0ct_2017.r1.

[32] Joseph Felsenstein. PHYLIP (phylogeny inference package), version 3.5 c. Joseph Felsenstein., 1993.

[33] Walter M. Fitch. "Toward Defining the Course of Evolution: Minimum Change for a Specific Tree Topology". In: Systematic Zoology 20.4 (Dec. 1971), p. 406. DOI: 10 . 2307 / 2412116. URL: https : //doi . org/10.2307 / 2412116.

[34] N Saitou and M Nei. "The neighbor-joining method: a new method for reconstructing phylogenetic trees." In: Molecular Biology and Evolution (July 1987). DOI: 10. 1093/oxfordjournals.molbev. a040454. URL: https:// doi.org/10.1093/oxfordjournals . molbev. a040454.

[35] C. F. J. Wu. "Jackknife, Bootstrap and Other Resampling Methods in Regression Analysis". In: The Annals of Statistics 14.4 (Dec. 1986). DOI: 10.1214/aos/ 1176350142. URL: https : / / doi .org/10 .1214/aos / 1176350142 .

[36] Marcela K Tello-Ruiz et al. "Gramene 2021: harnessing the power of comparative genomics and pathways for plant research". In: Nucleic Acids Research 49.D1 (Nov. 2020), pp. D1452-D1463. DOI: 10.1093/nar/gkaa979. URL: https://doi.org/10.1093/nar/gkaa979.

[37] David M. Goodstein et al. "Phytozome: a comparative platform for green plant genomics". In: Nucleic Acids Research 40.D1 (Nov. 2011), pp. D1178-D1186. DOI: 10. 1093/nar/gkr944. URL: https ://doi .org/10 .1093/ nar/gkr944.

[38] S. C. Potter. "The Ensembl Analysis Pipeline". In: Genome Research 14.5 (May 2004), pp. 934-941. DOI: 10 . 1101 /gr . 1859804. URL: https : / / doi . org/10 . $1101 / \mathrm{gr} .1859804$.

[39] Karin Verspoor et al. "A categorization approach to automated ontological function annotation". In: Protein Science (2006). ISSN: 09618368. DOI: $10.1110 / \mathrm{ps}$. 062184006. URL: https : //dx . doi .org/10.1110\%7B\% 5C\%7D2Fps. 062184006 .

[40] Michael Defoin-Platel et al. "AIGO: Towards a unified framework for the Analysis and the Inter-comparison of GO functional annotations". In: BMC Bioinformatics (2011). ISSN: 14712105. DOI: $10.1186 / 1471-2105-12-$ 431. URL: https ://doi .org/10 .1186/1471-2105-12431.

[41] Ilya Plyusnin, Liisa Holm, and Petri Törönen. "Novel comparison of evaluation metrics for gene ontology classifiers reveals drastic performance differences". In: PLOS Computational Biology 15.11 (Nov. 2019). Ed. by Predrag Radivojac, e1007419. ISSN: 1553-7358. DOI: 10. $1371 /$ journal . pcbi . 1007419. URL: http : / / dx . plos.org/10.1371/journal.pcbi.1007419.

[42] Ivica Letunic and Peer Bork. "Interactive Tree Of Life (iTOL) v5: an online tool for phylogenetic tree display and annotation". In: Nucleic Acids Research (Apr. 
bioRxiv preprint doi: https://doi.org/10.1101/2021.04.25.441366; this version posted May 24, 2021. The copyright holder for this preprint (which was not certified by peer review) is the author/funder, who has granted bioRxiv a license to display the preprint in perpetuity. It is REFERENCES made available under aCC-BY 4.0 International license.

2021). DOI: 10.1093/nar/gkab301. URL: https://doi . org/10.1093/nar/gkab301.

[43] Nancy Manchanda et al. "GenomeQC: a quality assessment tool for genome assemblies and gene structure annotations". In: BMC Genomics 21.1 (Mar. 2020), p. 193. ISSN: $1471-2164$. DOI: $10.1186 / \mathrm{s} 12864-020-6568-2$. URL: https : //doi .org/10.1186/s12864-020-6568-2 (visited on $03 / 12 / 2021$ ).

[44] Felipe A. Simão et al. "BUSCO: assessing genome assembly and annotation completeness with singlecopy orthologs". en. In: Bioinformatics 31.19 (Oct. 2015), pp. 3210-3212. ISSN: 1367-4803, 1460-2059. DOI: 10 . 1093 / bioinformatics / btv351. URL: https : / / academic .oup.com/bioinformatics/article-lookup/ doi / 10 . 1093 / bioinformatics / btv351 (visited on 03/12/2021).

[45] Shan Gao et al. "A high-quality reference genome of wild Cannabis sativa". en. In: Horticulture Research 7.1 (May 2020). Number: 1 Publisher: Nature Publishing Group, pp. 1-11. ISSN: 2052-7276. DOI: $10.1038 / \mathrm{s} 41438-020-$ 0295-3. URL: https : / / www . nature . com/articles / s41438-020-0295-3 (visited on 03/12/2021).

[46] Koichi Sakamoto et al. "Characterization Genome Sizes and Morphology of Sex Chromosomes in Hemp (Cannabis sativa L.)." In: CYTOLOGIA 63.4 (1998), pp. 459-464. DOI: $10.1508 /$ cytologia. 63.459 . URL: https://doi.org/10.1508/cytologia.63.459.

[47] Haley Dostalik and Carolyn Lawrence-Dill. Carolyn_Lawrence_Dill_GOMAP_Grape_Genoscope_12x_Jan 2021. DOI: 10 . 25739 / JTFK - Q888. URL: http : //datacommons . cyverse . org/browse/iplant/home / shared / commons_repo / curated / Carolyn_Lawrence _ Dill_GOMAP_Grape_Genoscope_12x_January_2021.r1.

[48] Leila Fattel and Carolyn Lawrence-Dill. Carolyn_Lawrence_Dill_GOMAP_Banana_NCBI_ASM31385v 2021. DOI: 10 . 25739 / YT7W - GS55. URL: http : //datacommons . cyverse . org/browse/iplant/home / shared / commons_repo/curated/Carolyn_Lawrence _ Dill _ GOMAP _ Banana _ NCBI _ ASM31385v2 _ February _ 2021.r1.

[49] Leila Fattel and Carolyn Lawrence-Dill. Carolyn_Lawrence_Dill_GOMAP_Cacao_NCBI_CriolloVV2_March_[60121Exa M Temsch and Johann Greilhuber. "Genome size 2021. DOI: 10 . 25739 / 9QCO - N310. URL: http : //datacommons . cyverse .org/browse/iplant/home / shared / commons_repo / curated / Carolyn_Lawrence _ Dill_GOMAP_Cacao_NCBI_CriolloV2_March_2021.r1.

[50] Dennis Psaroudakis and Carolyn Lawrence-Dill. Carolyn_Lawrence_Dill_GOMAP_Solanum_lycopersicum_ITA 2021. DOI: 10 . 25739 / ZH2V - 4P15. URL: http : //datacommons . cyverse .org/browse/iplant/home / shared / commons_repo / curated / Carolyn_Lawrence _ Dill_GOMAP_Solanum _ lycopersicum _ ITAG4 . 1 . v1 _ April_2021.r1.

[51] Dennis Psaroudakis and Carolyn Lawrence-Dill. Carolyn_Lawrence_Dill_GOMAP_Solanum_pennellii_Bolger2014. 6631$]$ A 2021. DOI: 10 . 25739 / FHR4 - CX67. URL: http : //datacommons . cyverse .org/browse/iplant/home / shared / commons_repo/curated / Carolyn_Lawrence _ Dill _ GOMAP _ Solanum _ pennellii _ Bolger2014 . v1 _ April_2021.r1.

[52] Ivica Letunic and Peer Bork. "Interactive Tree Of Life (iTOL) v4: recent updates and new developments". en. In: Nucleic Acids Research 47.W1 (July 2019), W256W259. ISSN: 0305-1048, 1362-4962. DOI: 10.1093/nar/ gkz239. URL: https : / / academic . oup . com / nar / article/47/W1/W256/5424068 (visited on 03/12/2021).

[53] Elizabeth A. Kellogg. "Evolutionary History of the Grasses". en. In: Plant Physiology 125.3 (Mar. 2001), pp. 1198-1205. ISSN: 0032-0889, 1532-2548. DOI: 10 . $1104 /$ pp . 125 . 3.1198. URL: https : / / academic . oup . com/plphys/article/125/3/1198-1205/6109905 (visited on $03 / 12 / 2021)$.

[54] Steven B. Cannon and Randy C. Shoemaker. "Evolutionary and comparative analyses of the soybean genome". eng. In: Breeding Science 61.5 (Jan. 2012), pp. 437-444. ISSN: 1344-7610. DOI: $10.1270 /$ jsbbs. 61 . 437.

[55] Candice N. Hansey et al. "Maize (Zea mays L.) genome diversity as revealed by RNA-sequencing". eng. In: PloS One 7.3 (2012), e33071. ISSN: 1932-6203. DOI: 10.1371/ journal.pone.0033071.

[56] Nasim Azani et al. "A new subfamily classification of the Leguminosae based on a taxonomically comprehensive phylogeny: The Legume Phylogeny Working Group (LPWG)". en. In: TAXON 66.1 (2017). _eprint: https://onlinelibrary.wiley.com/doi/pdf/10.12705/661.3, pp. 44-77. ISSN: 1996-8175. DOI: https://doi.org/10. 12705/661 . 3. URL: https : / / onlinelibrary . wiley . com/doi/abs/10.12705/661.3 (visited on 03/12/2021).

[57] Mark N. Puttick et al. "The Interrelationships of Land Plants and the Nature of the Ancestral Embryophyte". English. In: Current Biology 28.5 (Mar. 2018). Pub021 lisher: Elsevier, 733-745.e2. ISSN: 0960-9822. DOI: 10 . 1016/j . cub. 2018.01 .063. URL: https : / /www . cell . com / current - biology / abstract / S0960 - 9822(18) 30096-4 (visited on 03/12/2021).

[58] J. Doležel et al. "Letter to the editor". In: Cytometry 51A.2 (Jan. 2003), pp. 127-128. DOI: 10.1002/cyto.a.

https://doi.org/10.1002/cyto.a.10013.

[59] Mathieu Seppey, Mosè Manni, and Evgeny M. Zdobnov. "BUSCO: Assessing Genome Assembly and Annotation Completeness". In: Methods in Molecular Biology. Springer New York, 2019, pp. 227-245. DOI: 10.1007/ 978-1-4939-9173-0_14. URL: https : //doi .org/10 . 1007/978-1-4939-9173-0_14.

variation in Arachis hypogaea and A. monticola reevaluated". In: Genome 43.3 (June 2000), pp. 449-451. DOI: $10.1139 /$ g99-130. URL: https : // doi . org/10 . 1139/g99-130.

[61] Pilar Catalán et al. "Evolution and taxonomic split of G4.1.v1_Alpeitnde1.giass Brachypodium distachyon". In: Annals of Botany 109.2 (Jan. 2012), pp. 385-405. DOI: 10.1093/ aob/mcr294. URL: https : //doi .org/10 .1093/aob/ mcr294.

[62] Johann Greilhuber and Renate Obermayer. "Genome size and maturity group in Glycine max (soybean)". In: Heredity 78.5 (1997), pp. 547-551.

ApBil_HO2NDRIX. "Estimation of the Nuclear DNA Content of Gossypium Species". In: Annals of Botany 95.5 (Feb. 2005), pp. 789-797. DOI: 10.1093/aob/mci078. URL: https://doi.org/10.1093/aob/mci078.

[64] Michael David Bennett and JB Smith. "Nuclear DNA amounts in angiosperms". In: Philosophical Transactions: Biological Sciences (1991), pp. 309-345.

[65] Fatima Pustahija et al. "Small genomes dominate in plants growing on serpentine soils in West Balkans, an 
bioRxiv preprint doi: https://doi.org/10.1101/2021.04.25.441366; this version posted May 24, 2021. The copyright holder for this preprint (which was not certified by peer review) is the author/funder, who has granted bioRxiv a license to display the preprint in perpetuity. It is REFERENCES made available under aCC-BY 4.0 International license.

exhaustive study of 8 habitats covering 308 taxa". In: Plant and soil 373.1 (2013), pp. 427-453.

[66] Ka Arumuganathan and ED Earle. "Nuclear DNA content of some important plant species". In: Plant molecular biology reporter 9.3 (1991), pp. 208-218.

[67] AY Kenton, SJ Owens, and D Langton. "The origin of ringformation and self-compatibility in Gibasis pulchella (Commelinaceae)". In: Kew Chromosome Conference. Vol. 3. 1988, pp. 75-84.

[68] DA Laurie and MD Bennett. "Nuclear DNA content in the genera Zea and Sorghum. Intergeneric, interspecific and intraspecific variation". In: Heredity 55.3 (1985), pp. 307-313.

[69] A Parida, SN Raina, and RKJ Narayan. "Quantitative DNA variation between and within chromosome complements of Vigna species (Fabaceae)". In: Genetica 82.2 (1990), pp. 125-133. 
bioRxiv preprint doi: https://doi.org/10.1101/2021.04.25.441366; this version posted May 24,2021 . The copyright holder for this preprint (which was not certified by peer review) is the author/funder, who has granted bioRxiv a license to display the preprint in perpetuity. It is made available under aCC-BY 4.0 International license.

Table II: Quantitative metrics of the cleaned functional annotation sets. CC, MF, BP, and A refer to the aspects of the Gene Ontology: Cellular Component, Molecular Function, Biological Process, and Any/All. GOMAP covers all genomes with at least one annotation per gene and provides substantially more annotations than Gramene63 or Phytozome, especially in the BP aspect.

\begin{tabular}{|c|c|c|c|c|c|c|c|c|c|c|c|c|c|c|}
\hline \multirow[b]{2}{*}{ Genome } & \multirow[b]{2}{*}{ Genes } & \multirow[b]{2}{*}{ Dataset } & \multicolumn{4}{|c|}{ Genes Annotated $[\%]^{\mathrm{a}}$} & \multicolumn{3}{|c|}{ Annotations $^{\mathrm{b}}$} & \multicolumn{5}{|c|}{ Median Ann. per G } \\
\hline & & & $\mathrm{CC}$ & MF & $\mathrm{BP}$ & $\mathbf{A}$ & $\mathrm{CC}$ & $\mathrm{MF}$ & $\mathrm{BP}$ & $\mathbf{A} \mid$ & $\mathrm{CC}$ & {$[\mathrm{F}$} & $3 \mathrm{P}$ & \\
\hline Arachis hypogaea & 67,124 & GOMAP & 85.85 & 84.68 & 100.00 & 100.00 & 150,525 & 132,144 & 493,145 & 775,814 & 2 & 2 & 0 & \\
\hline \multirow{4}{*}{ Brachypodium distachyon } & \multirow{4}{*}{34,310} & GOMAP & 81.33 & 85.35 & 100.00 & 100.00 & 74,172 & 69,213 & 255,397 & 398,782 & 2 & 2 & 0 & \\
\hline & & GoldStandard & 21.54 & 19.53 & 18.20 & 26.66 & 10,985 & 10,436 & 11,120 & 32,673 & 1 & 1 & 1 & \\
\hline & & Gramene63-IEA & 33.12 & 49.29 & 38.29 & 63.60 & 21,658 & 36,372 & 23,899 & 82,026 & 1 & 1 & 1 & \\
\hline & & Phytozome12 & 10.25 & 37.21 & 26.86 & 43.11 & 4,186 & 18,597 & 11,070 & 34,060 & 0 & 1 & 1 & \\
\hline Cannabis sativa & 33,677 & GOMAP & 94.22 & 95.48 & 100.00 & 100.00 & 85,755 & 73,614 & 262,741 & 422,110 & 2 & 2 & 6 & \\
\hline Glycine $\max$ & 52,872 & GOMAP & 86.95 & 88.92 & 100.00 & 100.00 & 126,470 & 113,068 & 416,989 & 656,527 & 2 & 2 & 6 & \\
\hline Gossypium raimondii & 37,505 & GOMAP & 93.00 & 92.37 & 100.00 & 100.00 & 95,419 & 84,910 & 307,470 & 487,799 & 2 & 2 & 6 & \\
\hline \multirow{3}{*}{ Hordeum vulgare } & \multirow{3}{*}{39,734} & GOMAP & 88.57 & 91.76 & 100.00 & 100.00 & 86,489 & 79,727 & 272,420 & 438,636 & 2 & 2 & 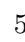 & \\
\hline & & GoldStandard & 28.23 & 26.30 & 23.43 & 35.64 & 15,734 & 15,391 & 15,267 & 46,414 & 1 & 1 & & \\
\hline & & Gramene63-IEA & 36.19 & 50.90 & 41.71 & 65.03 & 29,826 & 44,789 & 29,425 & 104,178 & 1 & 1 & 1 & \\
\hline \multirow{4}{*}{ Medicago truncatula A17 } & \multirow{4}{*}{50,444} & GOMAP & 83.79 & 86.69 & 100.00 & 100.00 & 104,902 & 99,155 & 363,608 & 567,665 & 2 & 2 & 0 & \\
\hline & & GoldStandard & 25.45 & 23.26 & 21.51 & 32.12 & 17,938 & 18,416 & 18,461 & 54,827 & 1 & 1 & & \\
\hline & & Gramene63-IEA & 34.25 & 50.84 & 40.26 & 66.14 & 32,753 & 63,470 & 40,441 & 137,001 & 1 & 1 & & \\
\hline & & Phytozome12 & 8.87 & 36.05 & 25.83 & 41.07 & 5,315 & 25,950 & 15,576 & 47,098 & 0 & 1 & 1 & \\
\hline Medicago truncatula R108 & 55,706 & GOMAP & 72.10 & 90.14 & 100.00 & 100.00 & 108,388 & 107,499 & 381,831 & $\mathbf{5 9 7 , 7 1 8}$ & 1 & 2 & & \\
\hline \multirow{4}{*}{ Oryza sativa } & \multirow{4}{*}{35,825} & GOMAP & 79.78 & 83.31 & 100.00 & 100.00 & 71,306 & 64,150 & 248,304 & 383,760 & 2 & 2 & & \\
\hline & & GoldStandard & 29.95 & 27.29 & 25.33 & 37.57 & 15,492 & 15,176 & 16,536 & 47,339 & 1 & 1 & 1 & \\
\hline & & Gramene63-IEA & 32.21 & 45.83 & 36.75 & 60.13 & 21,935 & 37,425 & 24,255 & 83,645 & 1 & 1 & & \\
\hline & & Phytozome12 & 10.31 & 40.10 & 29.18 & 46.09 & 4,361 & 20,842 & 12,451 & 37,884 & 0 & 1 & 1 & \\
\hline Phaseolus vulgaris & 27,433 & GOMAP & |94.48 & 93.06 & 100.00 & 100.00 & 70,987 & 64,022 & 229,230 & 364,239 & 2 & 2 & 0 & \\
\hline Pinus lambertiana & 31,007 & GOMAP & | 92.67 & 95.91 & 100.00 & 100.00 & 71,247 & 68,315 & 212,248 & 351,810 & 2 & 2 & & \\
\hline \multirow{4}{*}{ Sorghum bicolor } & \multirow{4}{*}{34,129} & GOMAP & 82.44 & 85.98 & 100.00 & 100.00 & 75,145 & 69,659 & 259,004 & 403,808 & 2 & 2 & 6 & \\
\hline & & GoldStandard & 34.48 & 32.91 & 30.90 & 42.84 & 16,837 & 17,614 & 17,850 & 52,593 & 1 & 1 & & \\
\hline & & Gramene63-IEA & 35.91 & 52.11 & 42.36 & 67.41 & 23,608 & 39,418 & 27,074 & 90,313 & 1 & 1 & 1 & \\
\hline & & Phytozome12 & 10.54 & 39.19 & 27.90 & 45.10 & 4,246 & 19,724 & 11,432 & 35,599 & 0 & 1 & & \\
\hline \multirow{3}{*}{ Triticum aestivum } & \multirow{3}{*}{107,891} & GOMAP & 88.53 & 90.98 & 100.00 & 100.00 & 259,318 & 217,467 & 785,051 & $1,261,836$ & 2 & 2 & 6 & \\
\hline & & GoldStandard & 2.98 & 2.78 & 2.56 & 3.82 & 4,727 & 4,512 & 4,793 & 14,035 & 1 & 1 & & \\
\hline & & Gramene63-IEA & 29.12 & 58.62 & 38.72 & 70.41 & 47,595 & 111,889 & 62,977 & 222,721 & 0 & 1 & 1 & \\
\hline \multirow{2}{*}{ Vigna unguiculata } & \multirow{2}{*}{29,773} & GOMAP & 91.21 & 91.08 & 100.00 & 100.00 & 74,791 & 67,734 & 242,847 & 385,372 & 2 & 2 & 6 & \\
\hline & & Phytozome12 & 13.91 & 45.68 & 34.14 & 53.06 & 5,107 & 19,962 & 12,209 & 37,534 & 0 & 1 & 1 & \\
\hline \multirow{3}{*}{ Zea mays B73.v4 } & & GOMAP & 93.16 & 94.92 & 100.00 & 100.00 & 87,648 & 81,665 & 278,305 & 447,618 & 2 & 2 & 6 & \\
\hline & 39,324 & GoldStandard & 37.92 & 34.78 & 32.67 & 46.85 & 22,531 & 21,292 & 23,153 & 67,285 & 1 & 1 & 1 & \\
\hline & & Gramene63-IEA & 39.16 & 58.16 & 48.21 & 73.87 & 30,189 & 53,748 & 35,276 & 119,273 & 1 & 1 & 1 & \\
\hline Zeu mags oviol & 0,020 & GoldStandard & 27.56 & 25.20 & 23.73 & 33.98 & 16,128 & 15,384 & 16,489 & 48,220 & 1 & 1 & 1 & \\
\hline Zea mays PH207 & 40.557 & GOMAP & 86.55 & 90.61 & 100.00 & 100.00 & 88,962 & 84,910 & 288,208 & 462,080 & 2 & 2 & 6 & \\
\hline & & GoldStandard & 28.18 & 25.82 & 24.26 & 34.66 & 17,370 & 16,580 & 17,791 & 51,984 & 1 & 1 & 1 & \\
\hline aus W22 & 40690 & GOMAP & 90.77 & 92.58 & 100.00 & 100.00 & 93,622 & 84,450 & 289,364 & 467,436 & 2 & 2 & 6 & \\
\hline Zea mays W22 & 40,690 & GoldStandard & 25.40 & 23.15 & 21.80 & 31.29 & 15,518 & 14,818 & 15,850 & 46,402 & 1 & 1 & 1 & \\
\hline
\end{tabular}

Download this table (CSV)

${ }^{\text {a }}$ How many genes in the genome have at least one GO term from the CC, MF, BP aspect annotated to them? A = How many at least one from any aspect? $(\mathrm{A}=\mathrm{CC} \cup \mathrm{MF} \cup \mathrm{BP})$

${ }^{\mathrm{b}}$ How many annotations in the $\mathrm{CC}, \mathrm{MF}$, and $\mathrm{BP}$ aspect does this dataset contain? $\mathrm{A}=\mathrm{How}$ many in total? $\mathrm{A}=\mathrm{CC}+\mathrm{MF}+\mathrm{BP}$

${ }^{\mathrm{c}}$ Take a typical gene that is present in the annotation set. How many annotations does it have in each aspect? A $=$ How many in total? Please note that $\mathrm{A} \neq \mathrm{CC}+\mathrm{MF}+\mathrm{BP}$ 
bioRxiv preprint doi: https://doi org/10.1101/2021.04.25.441366; this version posted May 24, 2021. The copyright holder for this preprint (which was not certified by peer review) is the author/funder, who has granted bioRxiv a license to display the preprint in perpetuity. It is made available under aCC-BY 4.0 International license.

Table III: Qualitative metrics of functional annotation sets predicted by GOMAP, Gramene, and Phytozome.

\begin{tabular}{|c|c|c|c|c|c|c|c|c|c|c|}
\hline \multirow[b]{2}{*}{ Genome } & \multirow[b]{2}{*}{ Dataset } & \multicolumn{3}{|c|}{ SimGIC2 } & \multicolumn{3}{|c|}{ TC-AUCPCR } & \multicolumn{3}{|c|}{ Fmax } \\
\hline & & $\mathrm{CC}$ & MF & $\mathrm{BP}$ & $\mathrm{CC}$ & MF & $\mathrm{BP}$ & $\mathrm{CC}$ & MF & $\mathrm{BP}$ \\
\hline \multirow{3}{*}{ Brachypodium distachyon } & GOMAP & 0.404149 & 0.464127 & 0.223830 & 0.233442 & 0.230701 & 0.118526 & 0.741361 & 0.740897 & 0.526881 \\
\hline & Gramene63-IEA & 0.317801 & 0.420859 & 0.349406 & 0.129163 & 0.192507 & 0.111361 & 0.691016 & 0.738542 & 0.650325 \\
\hline & Phytozome12 & 0.370264 & 0.370521 & 0.352206 & 0.112582 & 0.136832 & 0.085628 & 0.717759 & 0.697076 & 0.660603 \\
\hline \multirow{2}{*}{ Hordeum vulgare } & GOMAP & 0.400087 & 0.470012 & 0.238177 & 0.237231 & 0.261399 & 0.130784 & 0.745272 & 0.750213 & 0.560096 \\
\hline & Gramene63-IEA & 0.306119 & 0.426601 & 0.381010 & 0.157352 & 0.228797 & 0.136002 & 0.680996 & 0.742638 & 0.665696 \\
\hline \multirow{3}{*}{ Medicago truncatula A17 } & GO & 71795 & 0.451258 & 0.213407 & 0.272809 & 0.282650 & 0.139032 & 0.730838 & 0.726991 & 31406 \\
\hline & Gramene63-IEA & 0.329600 & 0.437274 & 0.343561 & 0.176497 & 0.265887 & 0.133503 & 0.701093 & 0.749900 & 0.654297 \\
\hline & Phytozome12 & 0.358311 & 0.367257 & 0.363013 & 0.144247 & 0.170863 & 0.110386 & 0.717307 & 0.698429 & 0.661233 \\
\hline \multirow{3}{*}{ Oryza sativa } & GOI & 0.408945 & 0.482650 & 0.248207 & 0.298502 & 0.303384 & 0.159724 & 1121 & 0.757181 & 59221 \\
\hline & Gramene63-IEA & 0.328761 & 0.423191 & 0.341193 & 0.167619 & 0.265410 & 0.135451 & 0.711309 & 0.738732 & 0.643827 \\
\hline & Phytozome12 & 0.049975 & 0.041007 & 0.044279 & 0.000003 & 0.000003 & 0.000002 & 0.470134 & 0.266628 & 0.239256 \\
\hline \multirow{3}{*}{ Sorghum bicolor } & GOI & 04852 & 0.466708 & 0.224011 & 0.316873 & 0.337380 & 0.169883 & 540 & 0.742001 & 4258 \\
\hline & Gramene63-IEA & 0.323037 & 0.400241 & 0.353135 & 0.177038 & 0.260198 & 0.154157 & 0.711107 & 0.712170 & 0.653591 \\
\hline & Phytozome12 & 0.356091 & 0.348264 & $=0.340124$ & 0.151947 & 0.177579 & 0.110483 & 0.715714 & 0.675147 & 0.641535 \\
\hline \multirow{2}{*}{ Triticum aestivum } & GOI & 0.410582 & 0.489881 & 0.229271 & 0.050762 & 0.030610 & 0.019360 & 476 & 0.762420 & 0.533897 \\
\hline & Gramene63-IEA & 0.362452 & 0.476685 & 0.395112 & 0.040992 & 0.043701 & 0.027872 & 0.737769 & 0.762059 & 0.670953 \\
\hline \multirow{2}{*}{ Zea mays B73.v4 } & GOMAP & 0.417455 & 0.467339 & 0.245373 & 0.302761 & 0.290371 & 0.153011 & 0.759504 & 0.746870 & 0.564707 \\
\hline & Gramene63-IEA & 0.303231 & 0.416301 & 0.346308 & 0.175735 & 0.250075 & 0.138275 & 0.662987 & 0.732860 & 0.647725 \\
\hline Zea mays Mo17 & GOMAP & |0.399521 & 0.464265 & 0.225632 & 0.236209 & 0.239598 & 0.125599 & 0.744360 & 0.743026 & 0.537489 \\
\hline Zea mays $\mathrm{PH} 207$ & GOMAP & | 0.394481 & 0.436266 & 0.224226 & | 0.221709 & 0.221266 & 0.117086 & 0.743111 & 0.718933 & 0.533092 \\
\hline Zea mays $\mathrm{W} 22$ & GOMAP & |0.397602 & 0.463499 & 0.223511 & 0.210198 & 0.217609 & 0.113262 & 0.743783 & 0.742341 & 0.535572 \\
\hline
\end{tabular}

Table IV: Assembly statistics from GenomeQC. Note well that the species and genome versions here are not guaranteed to agree with previous datasets in this analysis.

\begin{tabular}{|c|c|c|c|c|c|c|c|c|c|}
\hline & Scaffolds & $\begin{array}{l}\text { Total Scaffold } \\
\text { Length } \\
\text { (bp) }\end{array}$ & $\begin{array}{c}\text { Total Scaffold Length / } \\
\text { Estimated Genome Size } \\
(\%)\end{array}$ & $\begin{array}{l}\text { Scaffold Sequences } \\
>=25 \mathrm{~K} \mathrm{nt}\end{array}$ & $\begin{array}{c}\% \text { of Estimated Genome } \\
\text { with Scaffold Sequences } \\
\quad>=25 \mathrm{~K} \text { nt }\end{array}$ & $\% \mathrm{~N}$ & $\begin{array}{c}\text { Estimated } \\
\text { Genome Size } \\
(\mathrm{bp})\end{array}$ & $\begin{array}{l}\text { C-value } \\
\text { (pg) }\end{array}$ & $\begin{array}{c}\text { C-value } \\
\text { Ref. }\end{array}$ \\
\hline A. hypogaea & 384 & $2.56 \mathrm{E}+09$ & 91.12 & $2.55 \mathrm{E}+09$ & 91.01 & 0.15 & 2806 & 2.87 & {$[60]$} \\
\hline C. sativa & 221 & $8.76 \mathrm{E}+08$ & 106.72 & $8.75 \mathrm{E}+08$ & 106.62 & 15.93 & 821 & 0.84 & {$[46]$} \\
\hline G. $\max$ & 282 & $9.78 \mathrm{E}+08$ & 88.62 & $9.77 \mathrm{E}+08$ & 88.48 & 2.65 & 1105 & 1.13 & {$[62]$} \\
\hline G. raimondii & 1033 & $7.61 \mathrm{E}+08$ & 86.52 & $7.55 \mathrm{E}+08$ & 85.77 & 1.75 & 880 & 0.9 & {$[63]$} \\
\hline H. vulgare & 8 & $4.83 \mathrm{E}+09$ & 67.45 & $4.83 \mathrm{E}+09$ & 67.45 & 5.44 & 7167 & 7.33 & {$[64,65]$} \\
\hline M. truncatula R108 & 909 & $4.02 \mathrm{E}+08$ & 87.60 & $3.95 \mathrm{E}+08$ & 86.09 & 0.68 & 460 & 0.47 & {$[66]$} \\
\hline O. sativa & 63 & $3.75 \mathrm{E}+08$ & 76.85 & $3.75 \mathrm{E}+08$ & 76.74 & 0.03 & 489 & 0.5 & {$[64]$} \\
\hline P. vulgaris & 478 & $5.37 \mathrm{E}+08$ & 91.68 & $5.34 \mathrm{E}+08$ & 91.12 & 1.05 & 587 & 0.6 & {$[67]$} \\
\hline S. bicolor & 870 & $7.09 \mathrm{E}+08$ & 60.43 & $7.05 \mathrm{E}+08$ & 60.08 & 4.72 & 1173 & 1.2 & {$[68]$} \\
\hline T. aestivum & 22 & $1.45 \mathrm{E}+10$ & 86.00 & $1.45 \mathrm{E}+10$ & 86.00 & 1.90 & 16916 & 17.3 & {$[64]$} \\
\hline V. unguiculata & 686 & $5.19 \mathrm{E}+08$ & 88.64 & $5.18 \mathrm{E}+08$ & 88.38 & 0.00 & 587 & 0.6 & {$[69]$} \\
\hline Z. mays B73 & 266 & $2.13 \mathrm{E}+09$ & 80.85 & $2.13 \mathrm{E}+09$ & 80.85 & 1.44 & 2640 & 2.7 & {$[64]$} \\
\hline Z. mays Mo17 & 2208 & $2.18 \mathrm{E}+09$ & 82.68 & $2.17 \mathrm{E}+09$ & 82.06 & 1.61 & 2640 & 2.7 & {$[64]$} \\
\hline Z. mays $\mathrm{W} 22$ & 11 & $2.13 \mathrm{E}+09$ & 80.83 & $2.13 \mathrm{E}+09$ & 80.83 & 1.90 & 2640 & 2.7 & {$[64]$} \\
\hline
\end{tabular}


Table V: Structural annotation table directly from GenomeQC. Note well that the species and genome versions here are not guaranteed to agree with previous datasets in this analysis.

\begin{tabular}{|c|c|c|c|c|c|c|c|c|c|}
\hline Gene Models & $\begin{array}{l}\text { Min. } \\
\text { Gene Length } \\
\text { (bp) }\end{array}$ & $\begin{array}{l}\text { Max. } \\
\text { Gene Length } \\
\text { (bp) }\end{array}$ & $\begin{array}{l}\text { Avg. } \\
\text { Gene Length } \\
\text { (bp) }\end{array}$ & $\begin{array}{c}\text { Gene Models } \\
<200 \mathrm{bp}\end{array}$ & Transcripts & $\begin{array}{l}\text { Avg. Transcripts } \\
\text { per Gene Model }\end{array}$ & Exons & $\begin{array}{l}\text { Avg. Exons } \\
\text { per Transcript }\end{array}$ & $\begin{array}{l}\text { Avg. Exon } \\
\text { Length (bp) }\end{array}$ \\
\hline 67128 & 163 & 342359 & 3972.3 & 48 & 84714 & 1.3 & 423763 & 4.8 & 296.4 \\
\hline 36647 & 90 & 47411 & 3012.5 & 175 & 47917 & 1.3 & 263865 & 5.5 & 314.1 \\
\hline 29815 & 21 & 976063 & 3450 & 2187 & 34876 & 1.2 & 234157 & 6.6 & 291.9 \\
\hline 52872 & 90 & 94733 & 4017 & - & 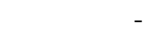 & - & - & - & \\
\hline 37505 & 90 & 51175 & 3243.5 & 71 & 77267 & 2.1 & 527563 & 6.7 & 271.3 \\
\hline & 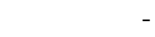 & - & & & 248270 & - & 1715898 & - & 278.9 \\
\hline 51541 & 60 & 102191 & 2566.9 & 1985 & 74213 & 1.4 & 318421 & 4.4 & 313.2 \\
\hline 55706 & 72 & 62996 & 2232.4 & 2404 & 61019 & 1.1 & 220904 & 3.6 & 270.6 \\
\hline 35825 & 72 & 304271 & 3098.7 & 57 & 42378 & 1.2 & 192499 & 4.5 & 350.3 \\
\hline 27433 & 93 & 90772 & 3943.8 & 108 & 36995 & 1.3 & - & - & - \\
\hline 34129 & 96 & 88337 & 3713.2 & 56 & 47121 & 1.4 & 266301 & 5.6 & 350.9 \\
\hline 107891 & 54 & 124945 & 3488.9 & 686 & 133744 & 1.2 & 749233 & 5.8 & 303.3 \\
\hline 29773 & 90 & 81066 & 3880.9 & 408 & 42287 & 1.4 & - & - & - \\
\hline 39324 & 111 & 128402 & 4117.8 & 38 & 151959 & 3.9 & 1488381 & 10 & 281.5 \\
\hline 38620 & 21 & 146217 & 4076.8 & 1225 & 46530 & 1.2 & 272323 & 5.9 & 297.1 \\
\hline 40557 & 111 & 714207 & 5993.3 & 53 & 40557 & 1.0 & 208149 & 5.1 & 252.1 \\
\hline 40691 & 87 & 154495 & 4330.4 & 64 & 51717 & 1.3 & 313830 & 6 & 292.4 \\
\hline
\end{tabular}

\begin{tabular}{lr} 
A. hypogaea & 67128 \\
B. distachyon & 36647 \\
C. sativa & 29815 \\
G. max & 52872 \\
G. raimondii & 37505 \\
H. vulgare & - \\
M. truncatula A17 & 51541 \\
M. truncatula R108 & 55706 \\
O. sativa & 35825 \\
P. vulgaris & 27433 \\
S. bicolor & 34129 \\
T. aestivum & 107891 \\
V. unguiculata & 29773 \\
Z. mays B73 & 39324 \\
Z. mays Mo17 & 38620 \\
Z. mays PH207 & 40557 \\
Z. mays W22 & 40691 \\
\multicolumn{2}{c}{ Download this table (CSV) }
\end{tabular}

Dashes (-) represent missing data. 


\section{a. Workflow Overview}

GO Annotation

Creation \&

Compilation

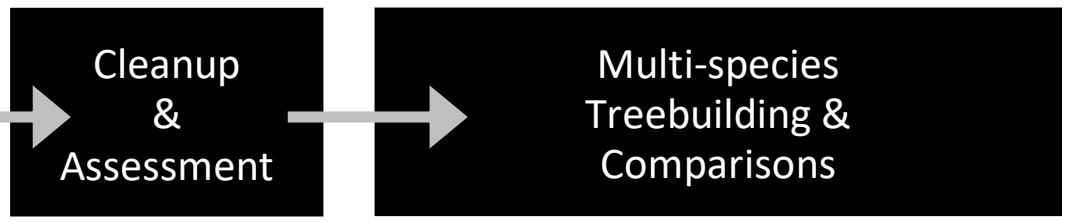

b. Workflow Detail

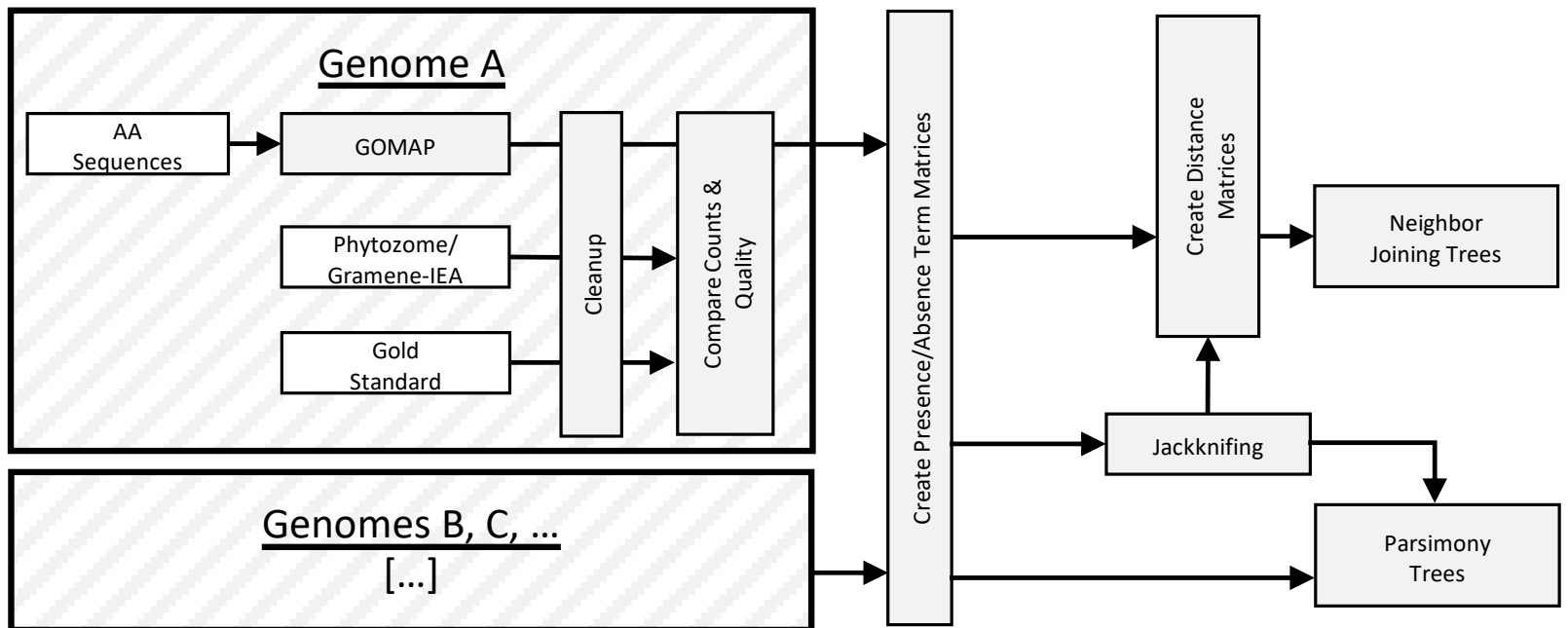




\section{Pinus lambertiana}

50

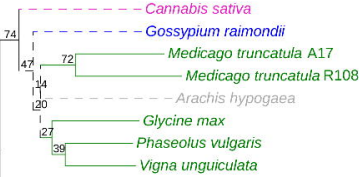

a.

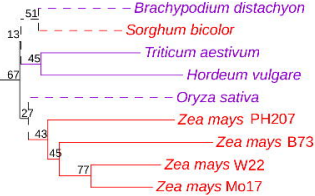

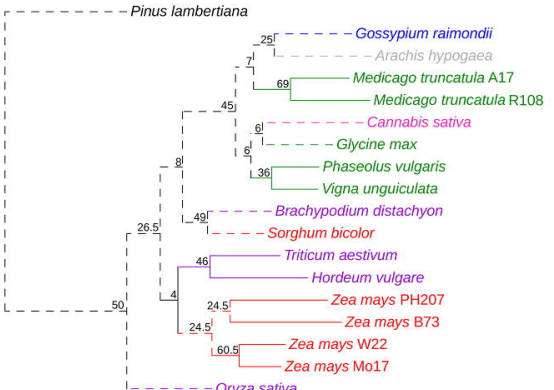

b. 
Tree scale: 0.1

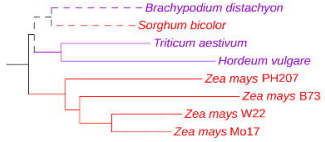

a.
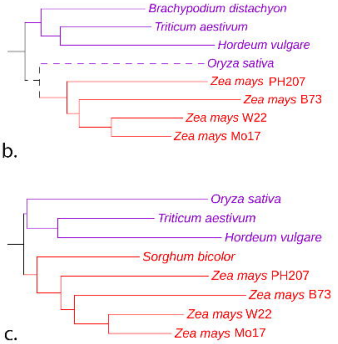
Pinus lambertiana

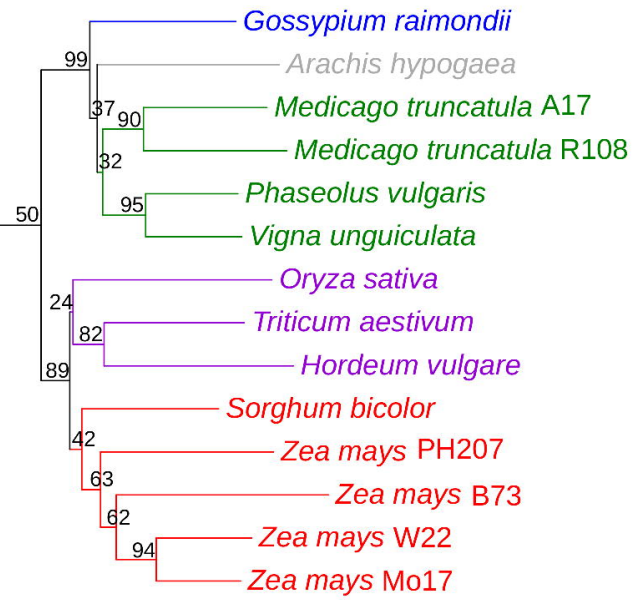




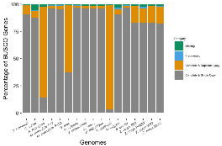




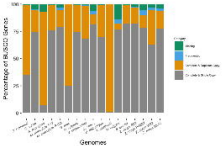

